\title{
DEVELOPMENT OF GEOPOLYMER (GREEN) CEMENT STRENGTH WITHOUT NATURAL AND CHEMICALS ADDITIVE.
}

\author{
${ }^{1}$ A. R. Abd EL-Moatey, ${ }^{2}$ I.El- Rashed, ${ }^{3}$ W.Al-Saed and W. H. Soufy ${ }^{4}$ \\ ${ }^{1}$ Civil Engineers - ministry of housing, utilities and new urban communities. \\ 2 projects mangment, Faculty of engineering, Ain shamis University. \\ ${ }^{3}$ Irrigation and Hydraulics. Faculty of Eng., Al-Azhar University \\ ${ }^{4}$ Housing and Building National Research Center (HBRC), Cairo, Egypt.
}

\begin{abstract}
Geopolymer cement (GPC) is made from aluminum and silicon, instead of calcium and silicon (OPC). Geopolymer are a type of inorganic polymer that can be formed at room temperature by using industrial waste (waste materials) such as ground granulated blast-furnace slag (GGBFS), Metakilon (MK) and Red mud (RD) or by products as source materials to form a solid binder that looks like and performs a similar function to OPC. Geopolymer concrete gets advantage specification in resistivity to highly aggressive media and the resistivity to change in mechanical and physical characterization at high temperature compared to the traditional concrete. this paper mainly study the preparation of Geopolymer cement to using in concrete instead of Portland cement and discuss the effect different factors on the compressive strength of Geopolymer paste without natural and chemicals additive (the effect ratio of (slag , Metakilon, Red mud, sodium hydroxide and sodium silicate) Four parameters were studied. The first parameter, the effect of changing ratio between sodium hydroxide and sodium silicate. $\mathrm{NaOH}$ : $\mathrm{Na} 2 \mathrm{SiO} 3$, secondly the effect of changing ratio between slag and Metakilon GGBFS :MK, thirdly the effect of changing ratio between slag and Red mud GGBFS :RM, fourthly the effect of changing degree curing temperature all samples curing different condition such as air, water, steam, oven. The results show that get high compressive strength at ratio between sodium hydroxide and sodium silicate $\left(\mathrm{NaOH}: \mathrm{Na}_{2} \mathrm{SiO}_{3}\right)$, slag and Metakilon (GGBFS :MK), slag and Red mud ( GGBFS :RM) is 1:2.5, 0.95:0.05, 0.90:0.10 respectively and the best mix have high compressive strength at various combinations between slag, Metakilon and Red mud by ratio GGBFS : MK : RM is 0.85:0.05:0.10. By inspecting the result it can be noticed that in case geopolymer concrete the best curing method gives high compressive strength in oven are compared air, steam, water and steam curing is better than air, water and air curing is better than water curing and the effect temperature curing type on compressive strength, Regardless of the compressive strength of samples increases with the increase in curing temperature.
\end{abstract}

\section{KEYWORDS: Kaolin Content and Alkaline Concentration, Strength Development,} Geopolymer cement, Red mud.

\section{INTRODUCTION}

Today one of the problems in building technology is the environmental pollution produced from cement. In the construction industry mainly the production of ordinary Portland cement (OPC) will cause the emission of pollutants which results in environmental pollution. There are three disadvantages of ordinary Portland cement the production. The emission of large amounts of carbon dioxide $\mathrm{CO}_{2}$ during the production of ordinary. Causing pollution of the 
atmosphere besides causing degradation of earth due to mining activities for limestone, Required Large amounts of energy.

Due to the excessive use of OPC, environmental concerns developed regarding the damage caused during the extraction of the raw materials and due to the large amount of $\mathrm{CO}_{2}$ emissions during the manufacturing process of OPC. It should be noted that the production of $\mathrm{OPC}$ is only an issue due to the large quantity that is produced each year. Compared to other materials, such as steel and aluminum, less energy is used to produce OPC. In seeking for solutions to reduce Global warming and the high amount of $\mathrm{CO}_{2}$ emissions, researchers introduced a new kind of binder known as alkali activated cement or better known as geopolymers cement.

The geopolymer technology shows considerable promise for application in the concrete industry as an alternative binder to the Portland cement. Proposed that an alkaline liquid could be used to react with the Silica (Si) and Aluminum (Al) in a source material of geological origin or in by product materials such as Ground Granulated Blast Furnace Slag (GGBS) powder, Metakilon to produce binders. Because the chemical reaction that takes place in this case is a polymerization process, the term geopolymer to represent these binders.

Geopolymer concrete there is often confusion between the meanings of the two terms 'geopolymer cement' and 'geopolymer concrete'. A cement is a binder whereas concrete is the composite material resulting from the addition of cement to stone aggregates. In other words, to produce concrete one purchase cements (generally Portland cement or Geopolymer cement) and adds it to the concrete batch. Geopolymer chemistry was from the start aimed at manufacturing binders and cements for various types of applications.

\section{Previous research}

In year 2015 Parthiban. K and Vaithianathan. S [1] Studied the strength characteristics of fly ash based geopolymer on different replacement levels of slag with met kaolin, sodium hydroxide concentration, maintaining the alkaline ratio constant at $\mathrm{NaOH}: \mathrm{Na}_{2} \mathrm{SiO}_{3}$ The tests includes cube compressive strength that approved that the compressive strength of geopolymer concrete increases with the increase in the Metakilon content and sodium hydroxide concentration. The mix with $12 \mathrm{M} \mathrm{NaOH}$ concentration and $20 \%$ Metakilon replacement shows optimum mix proportioning of the geopolymer concrete.

In year 2014 Sonal P. Thakkar, Darpan J. Bhorwani, Rajesh Ambaliya 3 [2] discusses various combinations of Ground Granulated Blast Furnace Slag (GGBFS) and Fly Ash, as source material, to produce geopolymer concrete at ambient temperature. Who that geopolymer concrete with GGBFS in Fly ash as increases it gains strength and shows good strength at 3, 7 and 28 days even at ambient curing with increase in GGBFS content. While only slag based geopolymer concrete has higher strength at oven curing while the rate of gain of strength is slower at ambient temperature as period increases.

In year 2014 Parthiban. K* and Saravana Raja Mohan. K [5] investigated has been made to study the variation in the Compressive Strength of slag based Geopolymer concrete of varying the concentration of Sodium hydroxide as $10,12,14 \mathrm{M}$ and the ratio of alkaline solution (SiO32- / OH-) as 1.0, 1.5, 2.0. The compressive strength of the mixes was determined in their 3, 7, 14 and 28 days curing for studying there variation at different age of curing. The test results show that the compressive strength of the Geopolymer mixes increases with the increase in the $\mathrm{NaOH}$ concentration and alkaline ratio.

In year 2015 Fenghong Fan [3] show that the Geopolymer cement cured at appropriate conditions can reach a compressive strength of more than $100 \mathrm{MPa}$ and it also has an excellent heat resistance with a remarkable strength after the $500^{\circ} \mathrm{C}$ heating. In addition, it is found that the studied Geopolymer cement possesses a much higher resistivity when immediately cooled down by water after the high temperature heating than the ordinary Portland cement concrete which has a high spallation tendency. These findings indicate that 
the Geopolymer cement may be an excellent construction material for the fire protection and fire-prone structures.

\section{Objective and scope}

Studying some factor effect on compressive strength such as the effect of Sodium silicate and sodium hydroxide $\left(\mathrm{Na}_{2} \mathrm{SiO}_{3}: \mathrm{NaOH}\right)$ with different curing type, the effect variation of degree curing Temperature for $24 \mathrm{hr}$, the Effect Meta-kaolin (MK)and red mud ratio. Then combination those to evaluate the high compressive strength of Geopolymer concrete mixture with Mk and RD replaced in percentage to G.G.B.S without usage of ordinary Portland cement

\section{Significance}

This paper aims to reduce the usage of ordinary Portland cement and to improve the usage of the other by product G.G.B.S (Slag). This product helps in reducing the carbon emissions caused by the conventional concrete. This also produces high strength concretes with the use of nominal mixes when compared to conventional concrete.

\section{Materials}

The used materials in the present study were ground granulated blast-furnace slag (GGBFS), meta-kaolin (MK), and Red mud (RD) and activator solution (the sodium hydroxide solution $\mathrm{NaOH}$, the sodium silicate solution $\mathrm{Na}_{2} \mathrm{SiO}_{3}$. Table (1) present the chemical composition of material that measured by $\mathrm{X}$ - ray flourresence.

\section{Ground granulated blast furnace slag (GGBFS)}

Ground granulated blast-furnace slag was obtained by Iron and Steel factory- Helwan, Egypt. The GGBFS is an industrial by-product resulting from rapid water cooling of molten steel. It is known to have advantageous properties for the concrete industry as it is relatively inexpensive to obtain highly resistant to chemical attack and maintains excellent thermal properties. Major components of the investigated slag are $\mathrm{SiO}_{2}, \mathrm{CaO}, \mathrm{MgO}$ and $\mathrm{Al}_{2} \mathrm{O}_{3}$ (Table 1). The Egyptian slag is characterized by its high content of $\mathrm{BaO}, \mathrm{MgO}$ and $\mathrm{MnO}$ than the common international standard one. GGBFS is off-white and grey in colour and substantially lighter than Portland cement. It was used as the basic aluminosilicate material to manufacture geopolymers.

\section{Meta-kaolin (MK):}

Kaolin material was extracted from the kaolinitic sandstone deposits existed in an open quarry located in Sinai west of Gebel Gunna by Middle East Mining Company Kaolin contains hydroxyl ions that are strongly bonded to the aluminosilicate framework and can only be altered by the temperature range $550-750{ }^{\circ} \mathrm{C}$ to be metakaolinite. Thus, rearranging the atomic structure to forma partly ordered system with a great reaction potential to alkaline solutions. The main chemical compositions of the studied meta- kaolin are $\mathrm{SiO}_{2}$ and $\mathrm{Al}_{2} \mathrm{O}_{3}$. Table (1) tabulated the chemical composition of calcined kaolin.

\section{Clay brick waste (Red mud (RM)).}

Clay brick waste (Red mud (RM)) can be defined as defective and crushed fired clay bricks. It was provided from clay brick factories, Helwan, Egypt. The main chemical compositions of the used RM are silica, alumina, in addition to a minor amount of iron oxides in a descending order of abundance (Table 1). 

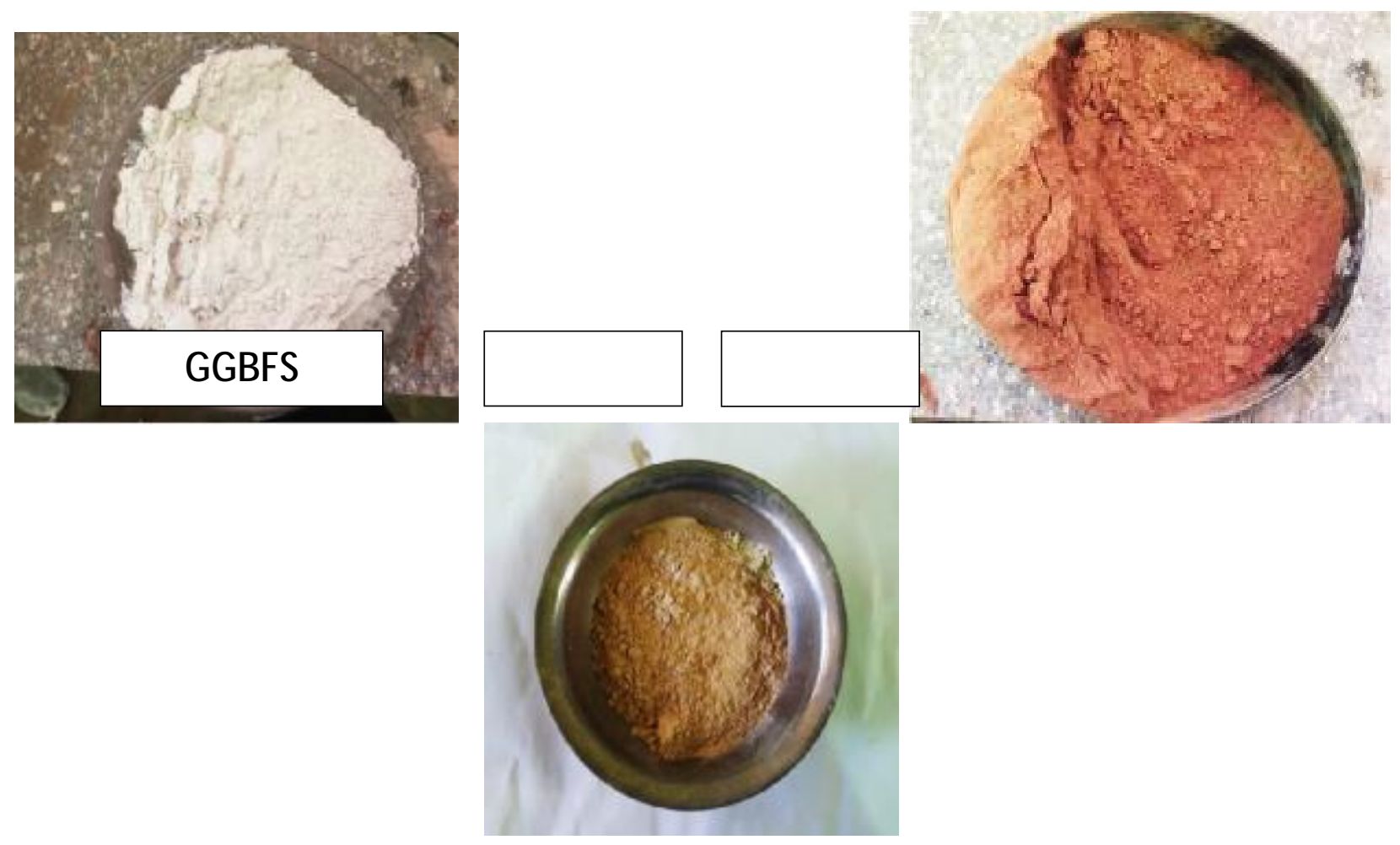

Figure (1) GGBFS, MK, RM

Table (1) X-ray (XRF) analysis of slag GGBFS, metakilon MK and Red mud RM.

\begin{tabular}{|c|c|c|c|c|c|c|c|c|c|c|c|c|c|c|}
\hline $\begin{array}{c}\text { Chemical } \\
\text { compounds }\end{array}$ & $\mathrm{CaO}$ & $\mathrm{SiO}_{2}$ & $\mathrm{Al}_{2} \mathrm{O}_{3}$ & $\mathrm{MgO}$ & $\mathrm{Na}_{2} \mathrm{O}$ & $\mathrm{SO}_{3}$ & $\mathrm{P}_{2} \mathrm{O}_{5}$ & $\mathrm{~K}_{2} \mathrm{O}$ & $\mathrm{TiO}_{2}$ & $\mathrm{MnO}_{2}$ & $\mathrm{Fe}_{2} \mathrm{O}_{3}$ & $\mathrm{SO}_{4}$ & $\mathrm{Cl}$ & $\mathrm{LOI}$ \\
\hline GGBS & 33.07 & $\mathbf{3 6 . 5 9}$ & $\mathbf{1 0 . 0 1}$ & $\mathbf{6 . 4 3}$ & $\mathbf{1 . 3 9}$ & $\mathbf{3 . 5 2}$ & $\mathbf{0 . 1 0}$ & $\mathbf{0 . 7 4}$ & $\mathbf{0 . 5 2}$ & $\mathbf{3 . 4 4}$ & $\mathbf{1 . 4 8}$ & $\mathbf{0 . 0 8}$ & $\mathbf{0 . 0 5}$ & $\mathbf{2 . 5 8}$ \\
\hline $\mathrm{RM}$ & $\mathbf{1 . 3 5}$ & $\mathbf{7 3 . 0 5}$ & $\mathbf{1 3 . 4 1}$ & $\mathbf{1 . 4 6}$ & $\mathbf{1 . 6 2}$ & $\mathbf{0 . 7 4}$ & $\mathbf{0 . 0 2}$ & $\mathbf{0 . 9 1}$ & $\mathbf{0 . 0 2}$ & $\mathbf{0 . 0 3}$ & $\mathbf{6 . 3 5}$ & $\mathbf{0 . 0 0}$ & $\mathbf{0 . 1 8}$ & $\mathbf{0 . 8 6}$ \\
\hline $\mathrm{MK}$ & $\mathbf{0 . 1 4}$ & $\mathbf{5 5 . 0 1}$ & $\mathbf{4 0 . 9 4}$ & $\mathbf{0 . 3 4}$ & $\mathbf{0 . 0 9}$ & $\mathbf{0 . 0 0}$ & $\mathbf{0 . 0 0}$ & $\mathbf{0 . 6 0}$ & $\mathbf{0 . 5 5}$ & $\mathbf{0 . 0 0}$ & $\mathbf{0 . 5 5}$ & $\mathbf{0 . 0 0}$ & $\mathbf{0 . 0 0}$ & $\mathbf{1 . 5 4}$ \\
\hline
\end{tabular}

\section{ACTIVATOR SOLUTION (NAOH, $\mathrm{NA}_{2} \mathrm{SIO}_{3}$ )}

Sodium silicate $\left(\mathrm{Na}_{2} \mathrm{SiO}_{3}\right)$ and Sodium hydroxide $(\mathrm{NaOH})$ based alkali activators were used for activating the geopolymerization process. $\mathrm{Na}_{2} \mathrm{SiO}_{3}$ is a white viscous liquid. Its chemical composition is $8.9 \% \mathrm{Na}_{2} \mathrm{O}, 28.7 \% \mathrm{SiO}_{2}$ and $62.5 \% \mathrm{H}_{2} \mathrm{O}$ (by weight) with specific gravity 1.41. $\mathrm{NaOH}$ is on form of white pellets with $99 \%$ purity. $\mathrm{NaOH}$ solution was prepared at desired molarity and kept in air for one day prior to mixing. With specific gravity 1.32 the concentration of the sodium hydroxide solution used from 12 molar (M) without additional water.

\section{Experimental Investigation}

\section{Preparation of Geopolymer paste}

$480 \mathrm{~g}$ (molarity x molecular weight) of sodium hydroxide flakes dissolved in one litre of water to prepare sodium hydroxide solution of $12 \mathrm{M}$. The mass of $\mathrm{NaOH}$ solids in a solution vary depending on the concentration of the solution

expressed in terms of molar, M. The mass of $\mathrm{NaOH}$ solids was measured as $372 \mathrm{~g}$ per $\mathrm{kg}$ of $\mathrm{NaOH}$ solution of $12 \mathrm{M}$ concentration. The sodium hydroxide solution is mixed with sodium silicate solution to get the desired alkaline solution one day before making the Geopolymer concrete. After solution is prepared the composition is weighed and mixed in concrete mixture as conventional concrete and transferred into moulds as early as possible as the setting times are low. 


\section{MIXING AND CASTING}

It was found that the fresh Geopolymer masonry mix was grey in colour and was cohesive. The amount of water in the mix played an important role on the behavior of fresh mix. Davidovits (2002) suggested that it is preferable to mix the sodium silicate solution and the sodium hydroxide solution together at least one day before adding the liquid to the solid constituents. The author suggested that the sodium silicate solution obtained from the market usually is in the form of a dimmer or a trimmer, instead of a monomer, and mixing it together with the sodium hydroxide solution assists the polymerization process.

Using the steel moulds Cubic's of $50 \times 50 \times 50 \mathrm{~mm}$ the one group is three cubic Following mixing, the materials were cast in prism moulds to produce samples of $50 \times 50 \times 50 \mathrm{~mm}$ for casting paste (binder, activator)

The effects of water content in the mix and the mixing time were identified as test parameters in the detailed study. From the preliminary work; it was decided to observe the following standard process of mixing in all further studies. Mix sodium hydroxide solution and sodium silicate solution together at least one day prior to adding the liquid to the dry materials. Mix all dry materials in the pan mixer for about three minutes. Add the liquid component of the mixture at the end of dry mixing, and continue the wet mixing for another four minutes. Compaction of fresh concrete in the cube moulds was achieved by compacting on a vibration table for ten seconds. After casting, the specimens were left undisturbed for 24 hours.

\section{CURING}

Curing is not required for these Geopolymer blocks. The heat gets liberated during the preparation of sodium hydroxide which should be kept undisturbed for curing in air. The moulds were covered by plastic film to avoid evaporation of water in case curing steam; the specimens were cured in water, oven at $80{ }^{\circ} \mathrm{C}$ for $24 \mathrm{hr}$

\section{TESTING}

The specimens were tested as per IS 516:1959 and strengths were calculated for 3, 7 and 28 days and the results were tabled.

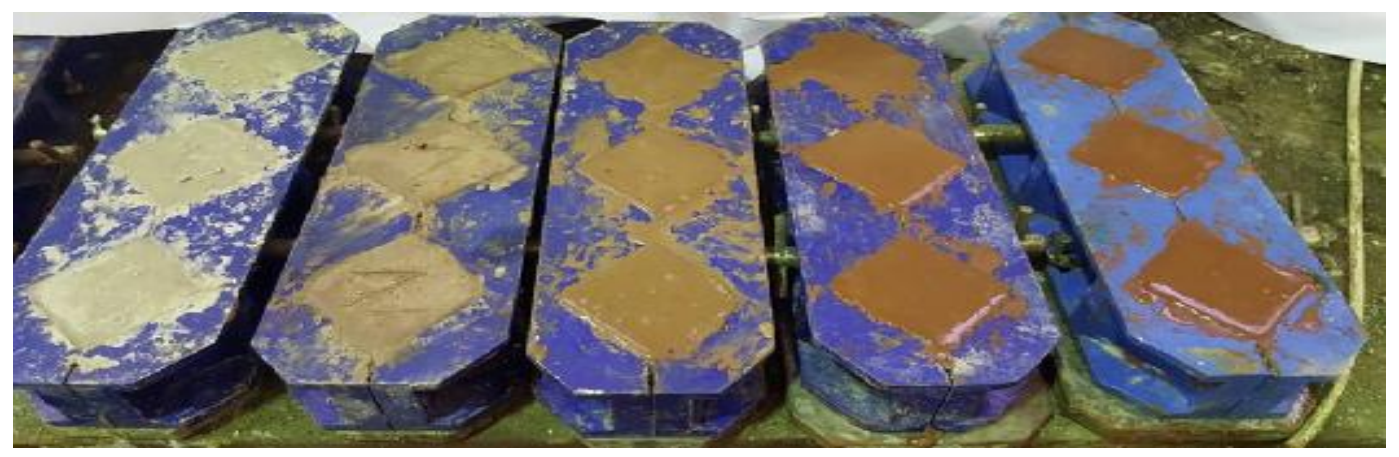

Figure 2 moulds $\mathbf{5 0} \times \mathbf{5 0} \times \mathbf{5 0} \mathrm{mm}$

\section{RESULTS AND DISCUSSION.}

\section{The effect of Sodium silicate and sodium hydroxide $\left(\mathrm{Na}_{2} \mathrm{SiO}_{3}: \mathrm{NaoH}\right)$ with different curing type}

Table (2) shows the compressive strength of geoplymer cement based slag "SN" samples with various Sodium silicate $\left(\mathrm{Na}_{2} \mathrm{SiO}_{3}\right)$ and Sodium hydroxide $(\mathrm{NaOH})$. And it can be noticed the effect curing type on compressive strength " water, air, wet air and oven " curing for 24 hours $\left(80^{\circ} \mathrm{C}\right)$ conditions. For all geopolymer mixes, the proportion of activator solution to geopolymer binder (24\%) by weight for paste. Also, reference samples of OPC were prepared with water cement ratio (W/C) of 0.25 in order to give the same workability of geopolymer pastes and due to the water required for cement paste of standard consistency test. 
DEVELOPMENT OF GEOPOLYMER (GREEN) CEMENT STRENGTH WITHOUT NATURAL AND CHEMICALS ADDITIVE.

Table (2) shown The Inflecune ratio of Sodium silicate and sodium hydroxide on compressive strength

\begin{tabular}{|c|c|c|c|c|c|c|c|c|c|c|c|c|c|c|c|c|}
\hline \multicolumn{17}{|c|}{ effect of $\mathrm{Na}_{2} \mathrm{Sio}_{3}$ ratio on compressive strength } \\
\hline \multirow[t]{2}{*}{ sample } & \multirow[t]{2}{*}{$\%$ slag } & \multirow[t]{2}{*}{$\% \mathrm{NaOH}$} & \multirow[t]{2}{*}{$\% \mathrm{Na}_{2} \mathrm{SiO}_{3}$} & \multirow[t]{2}{*}{$\mathrm{Na}_{2} \mathrm{SiO}_{3}: \mathrm{NaOH}$} & \multicolumn{4}{|c|}{$\mathrm{FC}_{3 \text { days }} \mathrm{Kg} / \mathrm{cm}^{2}$} & \multicolumn{4}{|c|}{$\mathrm{FC}_{7 \text { days }} \mathrm{Kg} / \mathrm{cm}^{2}$} & \multicolumn{4}{|c|}{$\mathrm{FC}_{28 \text { days }} \mathrm{Kg} / \mathrm{cm}^{2}$} \\
\hline & & & & & water & air & steam & oven & water & air & steam & oven & water & air & steam & oven \\
\hline OPC & $\mathbf{0}$ & $\mathbf{0}$ & $\mathbf{0}$ & OPC & 243 & 213 & 232 & 183 & 312 & 250 & 284 & 218 & 410 & 352 & 380 & 284 \\
\hline SNo & 100 & $\mathbf{0}$ & 1 & 01:00 & 20 & 26 & 43 & 185 & 32 & 45 & 67 & 213 & 88 & 112 & 119 & 219 \\
\hline SN1 & 100 & 4 & 1 & 0.25 & 204 & 213 & 224 & 485 & 268 & 305 & 324 & 490 & 398 & 456 & 478 & 560 \\
\hline SN2 & 100 & 3.5 & 1 & 0.28 & 216 & 223 & 236 & 496 & 294 & 312 & 336 & 512 & 408 & 472 & 494 & 575 \\
\hline SN3 & 100 & 3 & 1 & 0.33 & 219 & 234 & 245 & 503 & 298 & 314 & 349 & 526 & 413 & 488 & 500 & 587 \\
\hline SN4 & 100 & 2.5 & 1 & 0.4 & 221 & 237 & 251 & 530 & 306 & 319 & 359 & 544 & 418 & 494 & 512 & 610 \\
\hline SN5 & 100 & 2 & 1 & 0.5 & 225 & 241 & 259 & 544 & 316 & 328 & 362 & $\mathbf{5 5 0}$ & 434 & 506 & 518 & 612 \\
\hline SN6 & 100 & 1.5 & 1 & 0.66 & 234 & 245 & 270 & 567 & 328 & 337 & 375 & 576 & 464 & 529 & 540 & 637 \\
\hline SN7 & 100 & 1 & 1 & 1 & 260 & 274 & 287 & 590 & 341 & 348 & 380 & 612 & 471 & 538 & 545 & 645 \\
\hline SN8 & 100 & 1 & 1.5 & 1.5 & 300 & 324 & 334 & 632 & 353 & 364 & 391 & 640 & 483 & 544 & 564 & 680 \\
\hline SN9 & 100 & 1 & 2 & 2 & 342 & 357 & 363 & 670 & 373 & 386 & 408 & 690 & 488 & 550 & 573 & 688 \\
\hline SN10 & 100 & 1 & 2.5 & 2.5 & 358 & 372 & 385 & 688 & 395 & 412 & 420 & 713 & 540 & 568 & 590 & 720 \\
\hline SN12 & 100 & 1 & 3 & 3 & 352 & 361 & 389 & 677 & 380 & 394 & 411 & 695 & 490 & 559 & 612 & 691 \\
\hline SN13 & 100 & 1 & 3.5 & 3.5 & 296 & 308 & 321 & 540 & 318 & 331 & 342 & 548 & 402 & 412 & 415 & 490 \\
\hline SN14 & 100 & 1 & 4 & 4 & 210 & 218 & 228 & 442 & 245 & 228 & 245 & 481 & 370 & 376 & 384 & 371 \\
\hline SN15 & 100 & 1 & o & 0 & 188 & 203 & 210 & 312 & 196 & 217 & 219 & 316 & 212 & 226 & 239 & 320 \\
\hline
\end{tabular}

By inspecting the values in table (2), it can be concluded that sample SN10 gives the highest compressive strength over the other samples for all curing conditions. Regardless of the curing method, the compressive strength of samples increases with the increase in Sodium Silicate: Sodium hydroxide ratio $(\mathrm{Na} 2 \mathrm{SiO} 3: \mathrm{NaOH})$. This increase peaks at ratio of 2.5:1 then it reverses its pace. Also, it can be noticed that oven curing leads to the highest compressive strength for all samples, then steam curing, and then air curing and the least values are related to water curing (see figures 1,2, 3 and 4). Moreover, figure 5 illustrates that oven curing results in high early strength. 
DEVELOPMENT OF GEOPOLYMER (GREEN) CEMENT STRENGTH WITHOUT NATURAL AND CHEMICALS ADDITIVE.

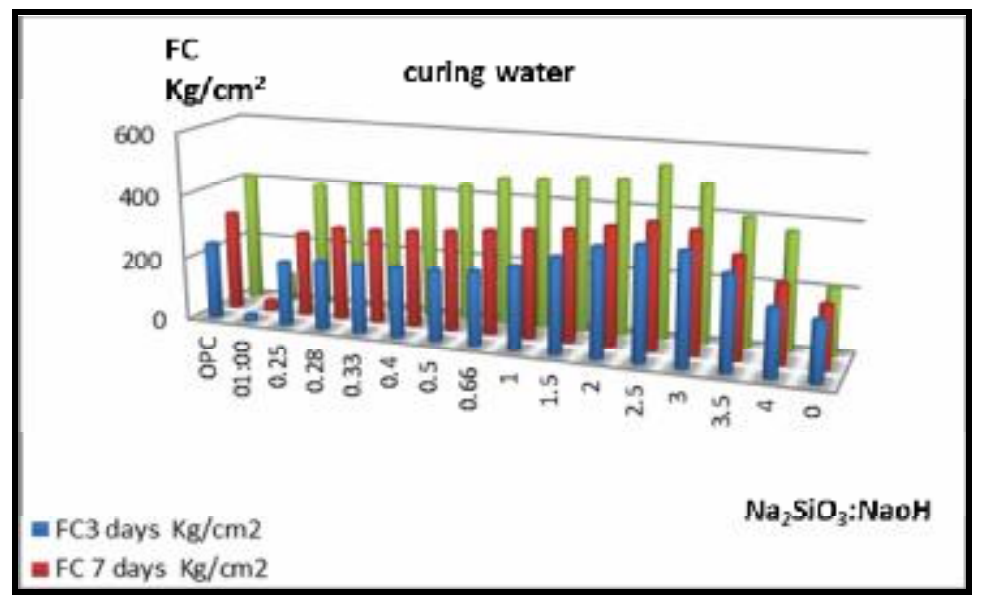

Figure (3) shown effect of $\mathrm{Na} 2$ sio3 ratio on compressive strength in case water curing

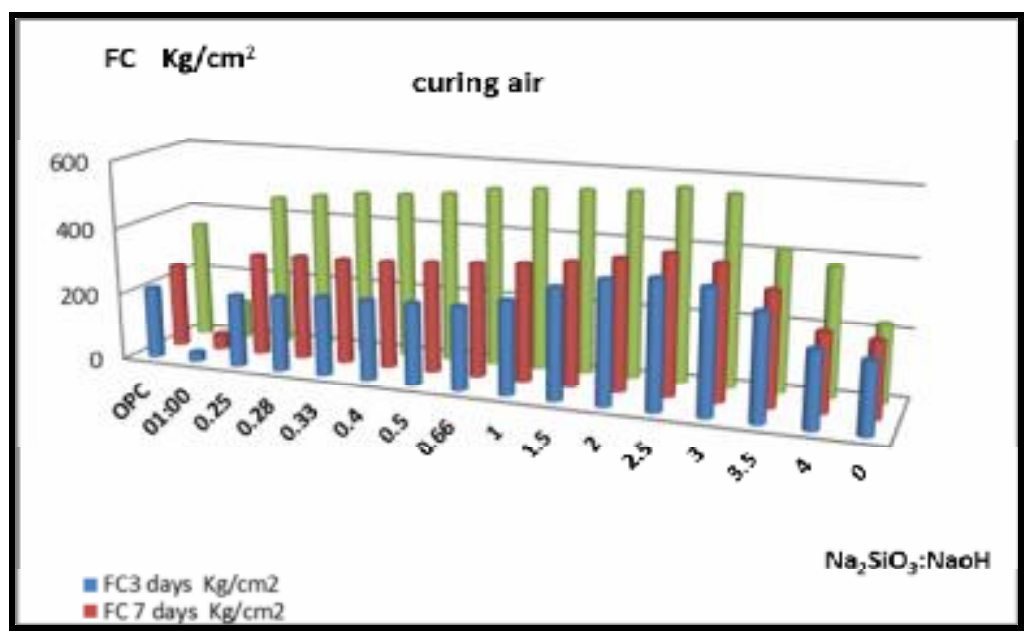

Figure (4) shown effect of $\mathrm{Na} 2 \operatorname{sio3}$ ratio on compressive strength in case air curing

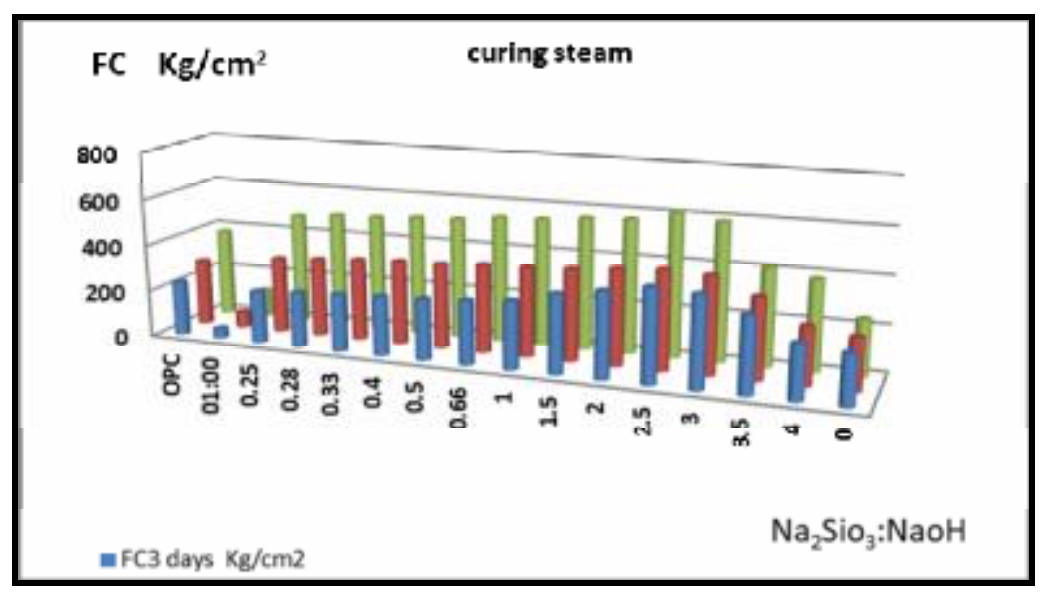

Figure (5) shown effect of $\mathrm{Na2sio3}$ ratio on compressive strength in case steam curing 


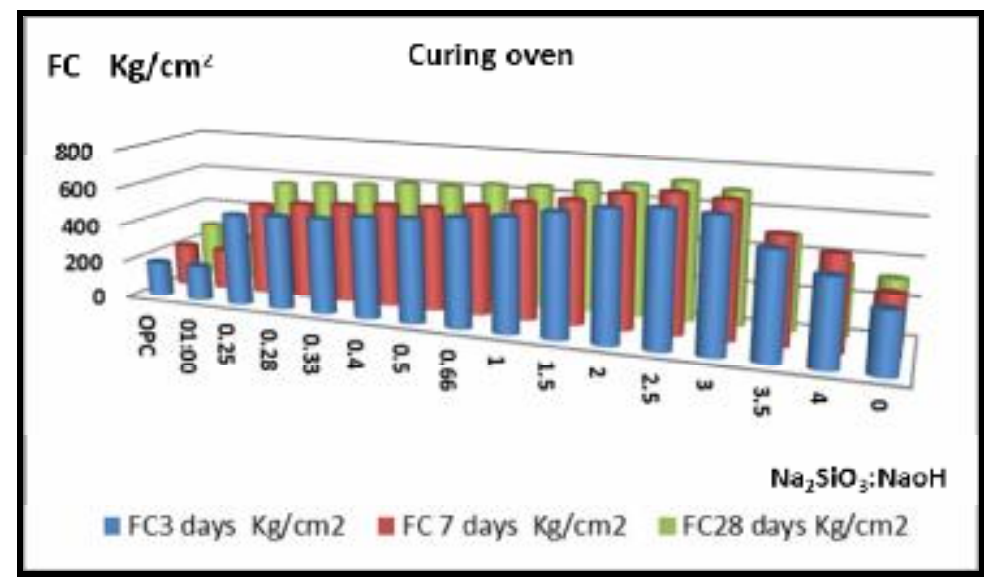

Figure (6) shown effect of $\mathrm{Na} 2 \operatorname{sio3}$ ratio on compressive strength in case oven curing

From fig $(3,4,5,6,7)$ can be concluded that in case Geopolymer concrete the best curing method gives high compressive strength in oven are compared air, steam, water, steam curing is better than air, water and air curing is better than water .

On the other side oven curing shows significant increase in compressive strength which reaches to 1.8 of water curing at 28 days and the most of strength geopolymer paste get in 3 day in case oven curing .

From fig $(3,4,5,6,7)$ can be concluded that in case Portland concrete the best curing method gives high compressive strength in water are compared air, steam, oven, steam curing is better than air, oven and air curing is better than oven.

\section{The variation of degree curing Temperature for $24 \mathrm{hr}$ on compressive strength}

Table (3) Shown The variation of degree curing temperature on compressive strength

\begin{tabular}{|c|c|c|c|c|c|c|c|c|c|}
\hline \multicolumn{10}{|c|}{ effect of degree curing temperature } \\
\hline sample & $\begin{array}{l}\text { slag } \\
(\mathrm{gm})\end{array}$ & $\begin{array}{c}\mathrm{NaoH} \\
(\mathrm{gm})\end{array}$ & $\begin{array}{c}\mathrm{Na}_{2} \mathrm{siO}_{3} \\
(\mathrm{gm})\end{array}$ & $\mathrm{Na}_{2} \mathrm{SiO}_{3}: \mathrm{NaOH}$ & T,Curing & $\mathrm{fc}_{3}$ & $\mathrm{fc}_{7}$ & $\mathrm{fc}_{28}$ & Curing \\
\hline $\mathrm{ST}_{1}$ & 1000 & 68.6 & 171.4 & 2.5 & 50 & 488 & 490 & 512 & \multirow{6}{*}{ oven } \\
\hline $\mathrm{ST}_{2}$ & 1000 & 68.6 & 171.4 & 2.5 & 60 & 554 & 562 & 571 & \\
\hline $\mathrm{ST}_{3}$ & 1000 & 68.6 & 171.4 & 2.5 & 70 & 569 & 576 & 594 & \\
\hline $\mathrm{ST}_{4}$ & 1000 & 68.6 & 171.4 & 2.5 & 80 & 590 & 595 & 622 & \\
\hline $\mathrm{ST}_{5}$ & 1000 & 68.6 & 171.4 & 2.5 & 90 & 616 & 618 & 640 & \\
\hline $\mathrm{ST}_{6}$ & 1000 & 68.6 & 171.4 & 2.5 & 100 & 643 & 647 & 680 & \\
\hline
\end{tabular}

Table (3) shows the compressive strength of geoplymer cement based slag "ST" samples with Sodium silicate $(\mathrm{Na} 2 \mathrm{SiO} 3)$ and Sodium hydroxide $(\mathrm{NaOH})$ is $2.5: 1$. And it can be noticed the effect temperature curing type on compressive strength, Regardless of the compressive strength of samples increases with the increase in curing temperature, Moreover, figure 8 illustrates that oven curing results in high early strength. By inspecting the values in fig 8 , it can be concluded that sample ST6 gives the highest compressive strength over the other samples for all curing temperature. 


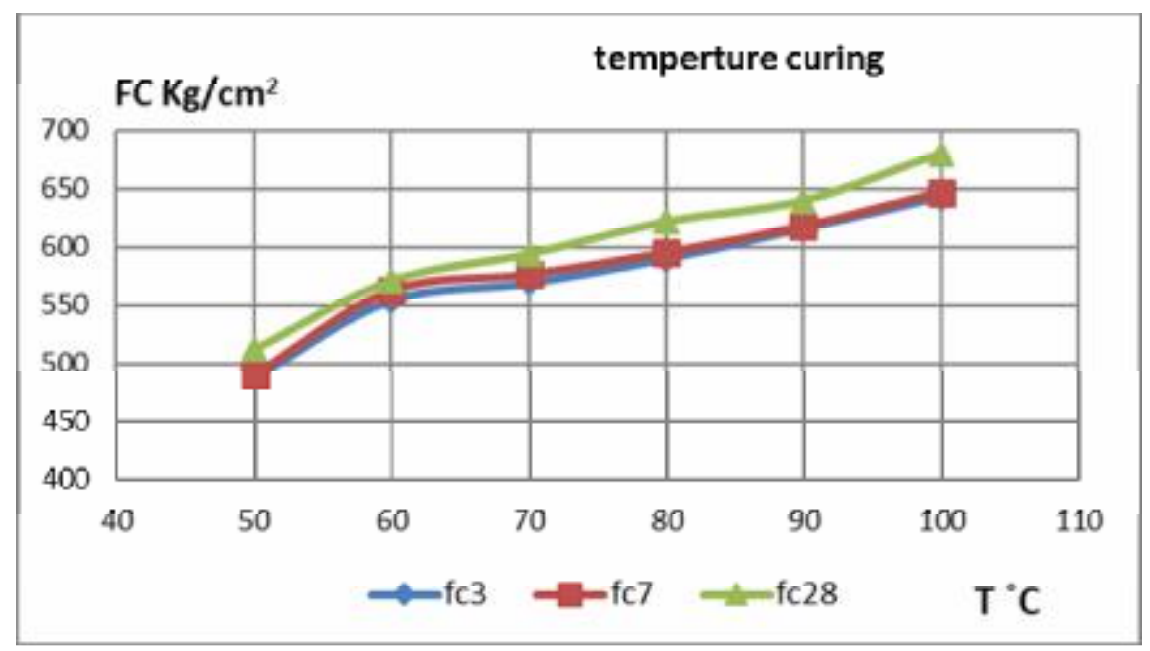

Figure (8) shown effect of curing temperature on compressive strength in case oven curing

\section{The effect Meta-kaolin (MK) on compressive strength}

In this part study effect metakoalin ratio on compressive strength slag - based Geopolymer, The replacement ratio ranged from 0 to $20 \%$ (by weight) for meta kaolin and the samples were denoted as "SM" samples. With Sodium silicate $\left(\mathrm{Na}_{2} \mathrm{SiO}_{3}\right)$ and Sodium hydroxide $(\mathrm{NaOH})$ is $2.5: 1$

Table (4) The Effect of M.K ratio on compressive strength

\begin{tabular}{|c|c|c|c|c|c|c|c|c|c|c|c|c|c|c|c|c|c|c|}
\hline \multicolumn{19}{|c|}{ effect of M.K ratio on compressive strength } \\
\hline \multirow{2}{*}{ sample } & \multirow{2}{*}{$\begin{array}{l}\text { slag } \\
(\mathrm{gm})\end{array}$} & \multirow{2}{*}{$\begin{array}{l}\text { M.K } \\
(\mathrm{gm})\end{array}$} & \multirow[t]{2}{*}{$\%$ M.K } & \multirow{2}{*}{$\begin{array}{l}\mathrm{NaoH} \\
(\mathrm{gm})\end{array}$} & \multirow{2}{*}{$\begin{array}{c}\mathrm{Na}_{2} \mathrm{Si}_{3} \\
(\mathrm{gm})\end{array}$} & \multirow{2}{*}{$\mathrm{Na}_{2} \mathrm{SiO}_{3} / \mathrm{NaOH}$} & \multicolumn{4}{|c|}{$\mathrm{FC}_{3 \text { days }} \mathrm{kg} / \mathrm{cm}^{2}$} & \multicolumn{4}{|c|}{$\mathrm{FC}_{7 \text { days }} \mathrm{kg} / \mathrm{cm}^{2}$} & \multicolumn{4}{|c|}{$\mathrm{FC}_{28 \text { days }} \mathrm{Kg} / \mathrm{cm}^{2}$} \\
\hline & & & & & & & water & air & steam & oven & water & air & steam & oven & water & air & steam & oven \\
\hline OPC & 1000 & $\mathrm{OPC}$ & OPC & OPC & OPC & OPC & 243 & 213 & 232 & 183 & 312 & 250 & 284 & 218 & 410 & 352 & 380 & 284 \\
\hline SM0 & 1000 & 0 & 0 & 68.6 & 171.4 & 2.5 & 358 & 372 & 385 & 688 & 395 & 412 & 420 & 713 & 540 & 568 & 590 & 720 \\
\hline SM1 & 950 & 50 & 5 & 68.6 & 171.4 & 2.5 & 390 & 398 & 412 & 725 & 445 & 461 & 468 & 737 & 551 & 574 & 598 & 742 \\
\hline SM2 & 900 & 100 & 10 & 68.6 & 171.4 & 2.5 & 362 & 370 & 385 & 690 & 411 & 450 & 453 & 702 & 549 & 571 & 587 & 720 \\
\hline SM3 & 850 & 150 & 15 & 68.6 & 171.4 & 2.5 & 347 & 361 & 373 & 678 & 407 & 420 & 426 & 685 & 534 & 542 & 550 & 690 \\
\hline SM4 & 800 & 200 & 20 & 68.6 & 171.4 & 2.5 & 334 & 344 & 350 & 661 & 398 & 408 & 417 & 670 & 529 & 537 & 541 & 677 \\
\hline
\end{tabular}

Table (4) shows that the highest compressive strength was obtained in sample $\mathrm{SM}_{1}$ (replacement ratio $=5 \%$ ). Also, the compressive strength ratio between 7 and 28 days ranged from about 0.75 to 0.90 . This ratio tends to increase with the increase in MK replacement ratio. In air (ambient) curing, table 4 shown increases in compressive strength of Geopolymer cement based on slag with Meta Kaolin as a replacement material with time and this increase gets highly strength at sample $\mathrm{SM}_{1}$. These behaviors are matched with above determinations in air. But, in air the results get more strength values due to the vaporization of external water in geopolymer cement.

From fig $(9,10,11$, and 12) shown that geopolymer paste the best curing method gives high compressive strength in oven are compared air, steam and water.

Steam curing is better than air, water and air curing is better than water. We notice too that MK replacement ratio gives the best results incase offer to temperature. 
DEVELOPMENT OF GEOPOLYMER (GREEN) CEMENT STRENGTH WITHOUT NATURAL AND CHEMICALS ADDITIVE.

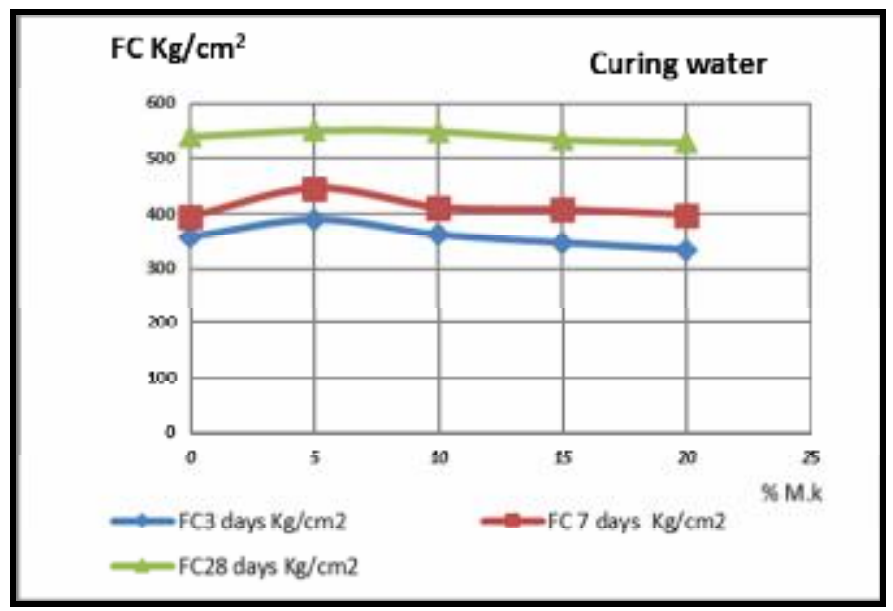

Figure (9) effect of M.K ratio on compressive strength in case water curing

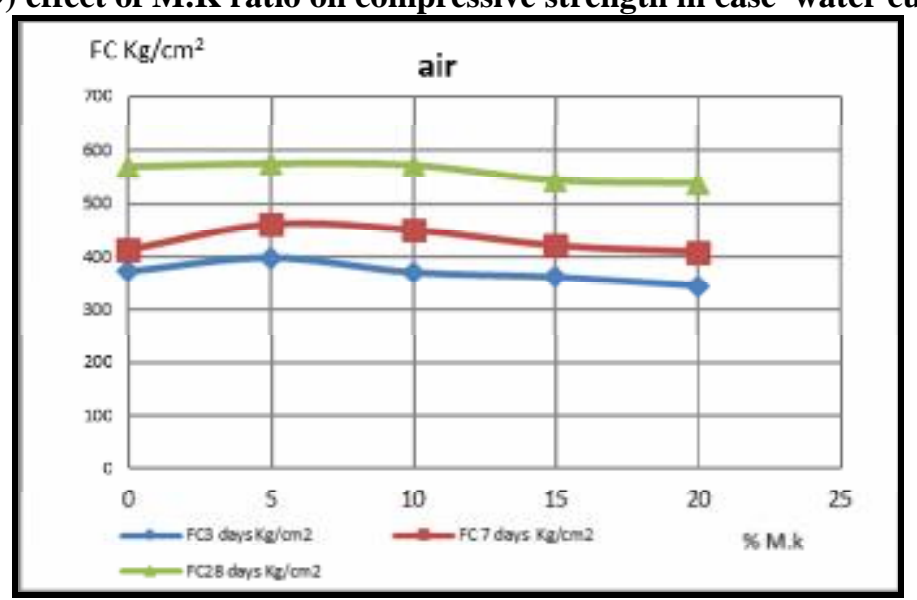

Figure (10) effect of M.K ratio on compressive strength in case air curing

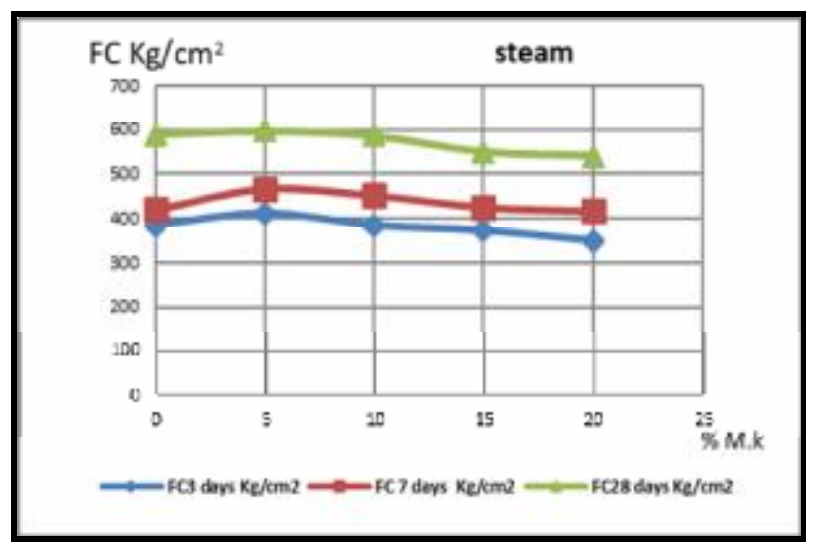

Figure (11) effect of M.K ratio on compressive strength in case steam curing 


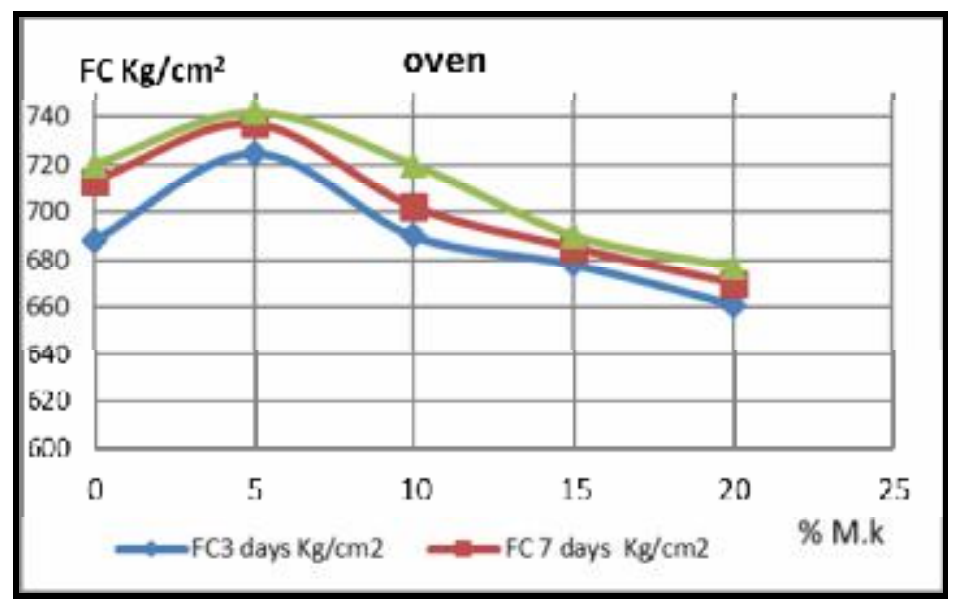

Figure (12) effect of M.K ratio on compressive strength in case oven curing

\section{The effect Red mud (R.M) on compressive strength}

In this part study effect red mud ratio on compressive strength slag - based Geopolymer, The replacement ratio ranged from 0 to $20 \%$ (by weight) for for red brick and the samples were denoted as "SR" samples. With Sodium silicate $\left(\mathrm{Na}_{2} \mathrm{SiO}_{3}\right)$ and Sodium hydroxide $(\mathrm{NaOH})$ is $2.5: 1$

Table (5) shown The Effect of RM ratio on compressive strength

\begin{tabular}{|c|c|c|c|c|c|c|c|c|c|c|c|c|c|c|c|c|c|c|c|}
\hline \multicolumn{20}{|c|}{ Effect of R.D ratio on compressive strength } \\
\hline \multirow{2}{*}{$\begin{array}{l}\text { sam } \\
\text { ple }\end{array}$} & \multirow{2}{*}{$\begin{array}{l}\text { slag } \\
(\mathrm{gm})\end{array}$} & \multirow{2}{*}{$\begin{array}{c}\mathbf{R M} \\
(\mathbf{g m})\end{array}$} & \multirow{2}{*}{$\% \mathrm{RM}$} & \multirow{2}{*}{$\begin{array}{c}\text { total } \\
\text { solati } \\
\text { on gm }\end{array}$} & \multirow{2}{*}{$\begin{array}{c}\mathrm{NaoH} \\
(\mathrm{gm})\end{array}$} & \multirow{2}{*}{$\begin{array}{c}\mathrm{Na}_{2} \mathrm{Sio}_{3} \\
(\mathrm{gm})\end{array}$} & \multirow{2}{*}{$\begin{array}{l}\mathrm{Na}_{2} \mathrm{SiO}_{3} / \\
\mathrm{NaOH}\end{array}$} & \multicolumn{4}{|c|}{$\mathrm{FC}_{3 \text { days }} \mathrm{Kg} / \mathrm{cm}^{2}$} & \multicolumn{4}{|c|}{$\mathrm{FC}_{7 \text { days }} \mathrm{Kg} / \mathrm{cm}^{2}$} & \multicolumn{4}{|c|}{$\mathrm{FC}_{28 \text { days }} \mathrm{Kg} / \mathrm{cm}^{2}$} \\
\hline & & & & & & & & water & air & steam & oven & water & air & Steam & oven & water & air & $\begin{array}{c}\text { stea } \\
\text { m }\end{array}$ & oven \\
\hline OPC & 1000 & OPC & OPC & 220 & OPC & OPC & OPC & 243 & 213 & 232 & 183 & 312 & 250 & 284 & 218 & 410 & 352 & 380 & 284 \\
\hline SR0 & 1000 & $\mathbf{0}$ & $\mathbf{0}$ & 240 & 68.6 & 171.4 & 2.5 & 358 & 372 & 385 & 695 & 395 & 412 & 420 & 704 & 540 & 568 & 590 & $\mathbf{7 2 0}$ \\
\hline SR1 & 950 & 50 & 5 & 240 & 68.6 & 171.4 & 2.5 & 374 & 395 & 398 & 701 & 414 & 429 & 442 & 710 & 553 & 589 & 604 & 722 \\
\hline SR2 & 900 & 100 & 10 & 260 & 74.29 & 185.7 & 2.5 & 434 & 470 & 482 & 718 & 471 & 496 & 510 & 723 & 608 & 622 & 653 & 727 \\
\hline SR3 & 850 & 150 & 15 & 280 & 80 & 200 & 2.5 & 420 & 433 & 456 & 706 & 457 & 470 & 478 & 714 & 564 & 599 & 612 & 725 \\
\hline SR4 & 800 & 200 & 20 & 300 & 85.71 & 214.3 & 2.5 & 389 & 400 & 434 & 703 & 427 & 449 & 461 & 712 & 559 & 590 & 608 & 723 \\
\hline
\end{tabular}

Table ( 5) depicts that the highest compressive strength was obtained in sample SR2 (replacement ratio $=10 \%$ ). Also, compressive strength gains at 7 days reached about $90 \%$ of its compressive strength at age 28 days. For the other samples, this ratio varied between 55 to $110 \%$ which means that number of samples suffered strength loss at 28 days. Moreover, sample SR4 which corresponds to the full replacement of GGBFS by RB shows the less compressive strength in comparison to other SR mixes. In air (ambient) curing, table 5 shown increases in compressive strength of Geopolymers cement based on slag with Red bricks as a replacement material with time and this increase gets highly strength at sample R2. 
DEVELOPMENT OF GEOPOLYMER (GREEN) CEMENT STRENGTH WITHOUT NATURAL AND CHEMICALS ADDITIVE.

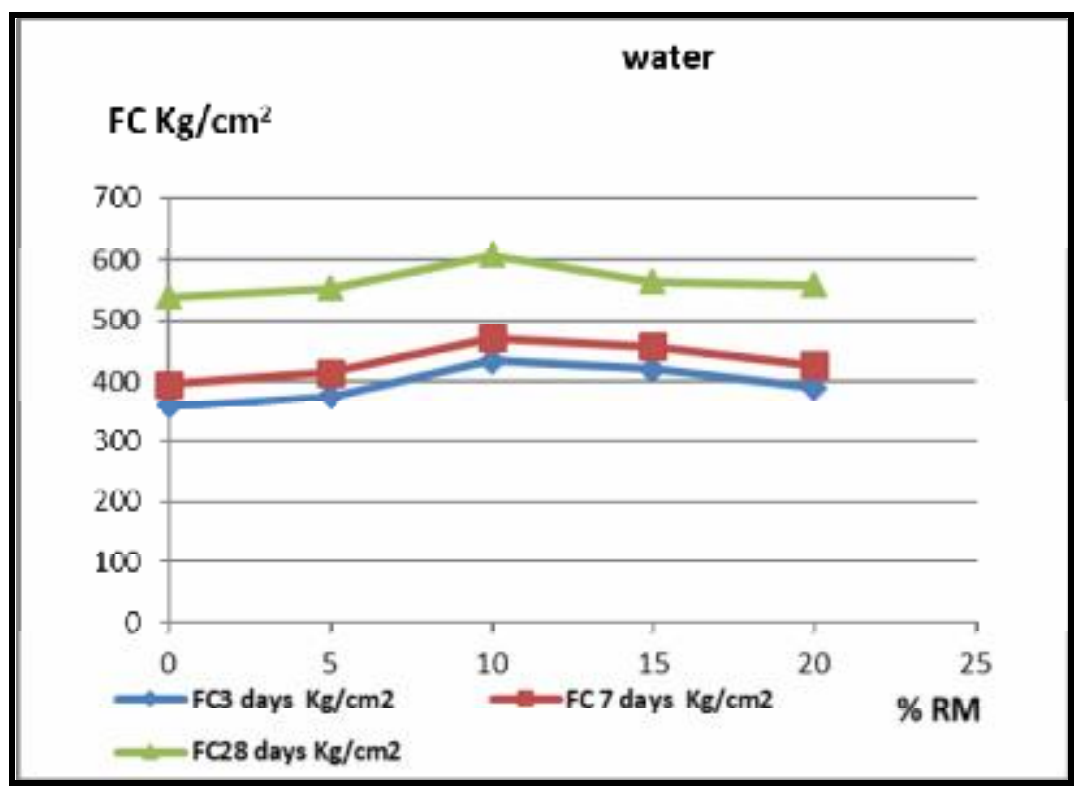

Figure (13) effect of $R D$ ratio on compressive strength in case water curing

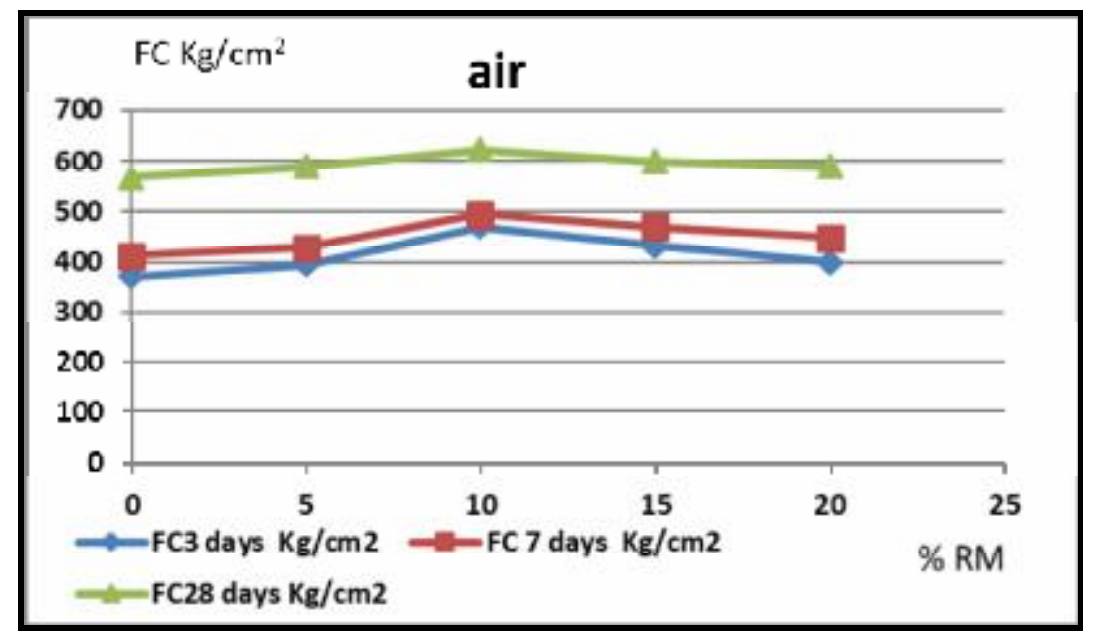

Figure (14) effect of $R D$ ratio on compressive strength in case air curing

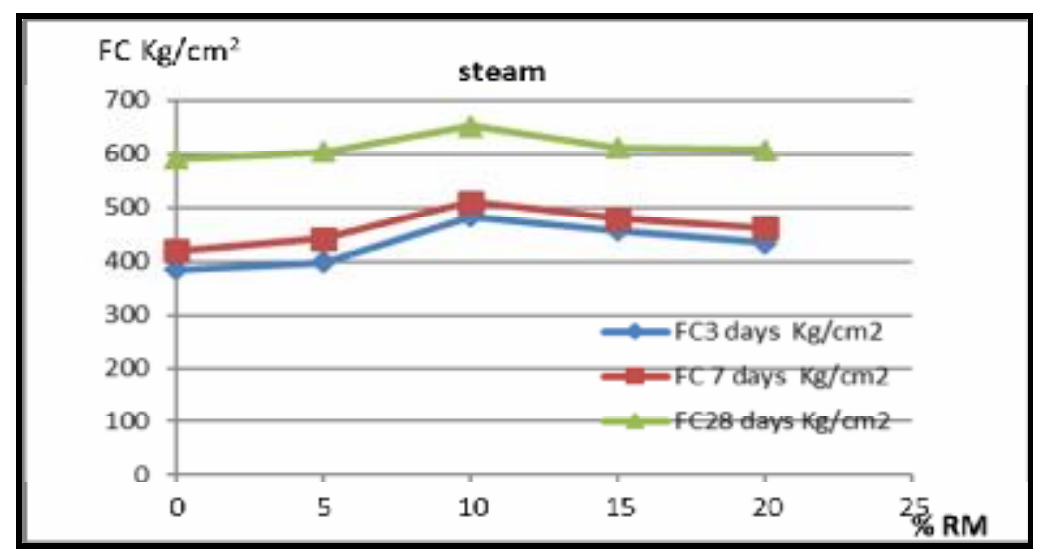

Figure (15) effect of RM ratio on compressive strength in case steam curing 


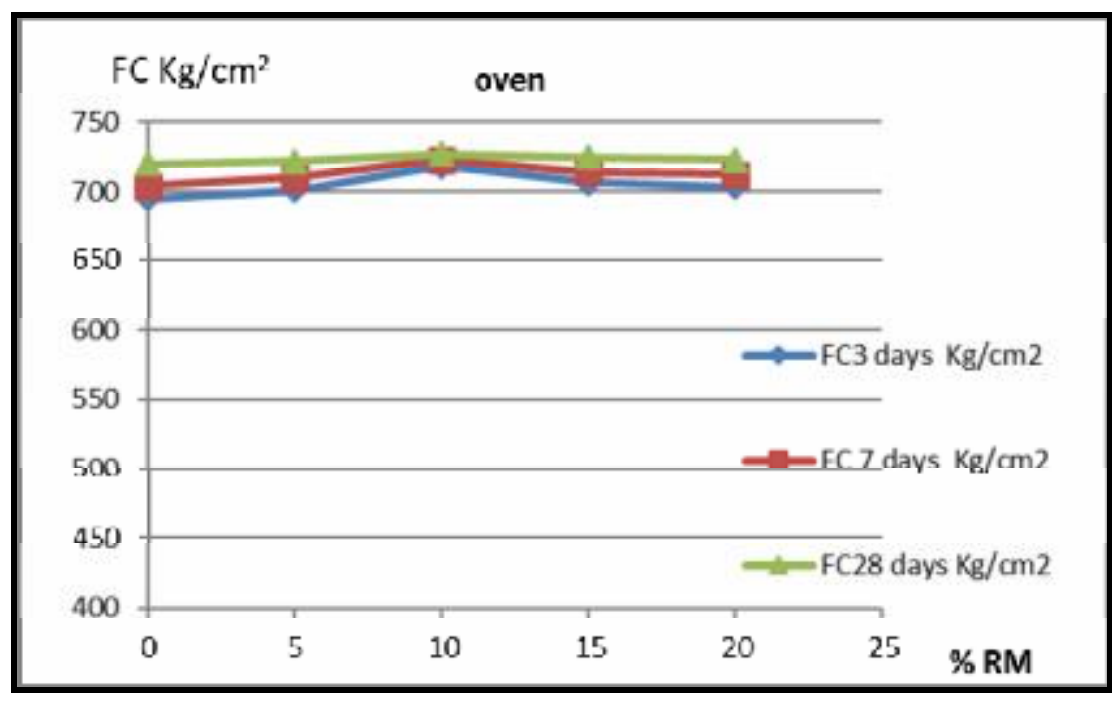

Figure (16) effect of M.K ratio on compressive strength in case oven curing

From fig $(13,14,15$ and 16) shown that geopolymer paste the best curing method gives high compressive strength in oven are compared air, steam and water.

steam curing is better than air, water and air curing is better than water. We notice too that RM replacement ratio gives the best results incase offer to temperature.

\section{COMBINATION OF NA2 $\mathrm{SIO}_{3}$ : NAOH, R.M AND M.K RATIO ON COMPRESSIVE STRENGTH.}

It is obvious that the partial replacements of GGBS by RM, MK, or a combination of some of them lead to higher compressive strengths. Also, all geopolymer samples showed higher strength than OPC with the same water ratio. The combination of factors to get high compressive strength ("SN", "ST", "SM", "SR") and the sample was denoted as "SP" samples. Table 6 gives a summary of chosen samples to be exposed to mechanical to OPC and SMR samples. As concluded from the previous tables samples $\mathrm{SN}_{10}, \mathrm{SR}_{2}$ and $\mathrm{SM}_{1}$ had shown highest compressive strength.

Figure $(16,17,18)$ shows the best ratio of activator solution, Sodium silicate $\left(\mathrm{Na}_{2} \mathrm{SiO}_{3}\right)$ and Sodium hydroxide $(\mathrm{NaOH})$ ratio is $\mathbf{S N}_{\mathbf{1 0}}$, the best that the partial replacements of GGBS by $\mathrm{MK}$ is $\mathbf{S M}_{\mathbf{1}}$, the best that the partial replacements of GGBS by RM is $\mathbf{S M}_{\mathbf{1}}$ and combination of $\mathbf{S M}_{\mathbf{1}}, \mathbf{S M}_{\mathbf{1}}$ and $\mathbf{S N}_{\mathbf{1 0}}$ to get $\mathbf{S M R}$ ( combined GGBFS +RM + MK )have higher compressive strength than $\mathbf{S M}_{\mathbf{1}}, \mathbf{S M}_{\mathbf{1}}, \mathbf{S N}_{\mathbf{1 0}}$ after 3,7 and 28 days. 
DEVELOPMENT OF GEOPOLYMER (GREEN) CEMENT STRENGTH WITHOUT NATURAL AND CHEMICALS ADDITIVE.

Table (6) shown Optimizations of Na2SiO3: NaoH, R.D and M.K ratio

\begin{tabular}{|c|c|c|c|c|c|c|c|c|c|c|c|c|c|c|c|c|c|c|c|c|c|}
\hline \multirow[b]{3}{*}{ sample } & \multicolumn{21}{|c|}{ Optimizations of $\mathrm{Na}_{2} \mathrm{SiO}_{3}: \mathrm{NaoH} \&$ R.D and $\mathrm{M} . \mathrm{K}$ ratio on compressive strength } \\
\hline & \multirow{2}{*}{ 焉 } & \multirow{2}{*}{$\sum_{\underline{\alpha}} \widehat{\dot{\vec{g}}}$} & \multirow{2}{*}{$\begin{array}{l}\sum_{\substack{0 \\
0}}^{0} \\
\delta^{\circ}\end{array}$} & \multirow{2}{*}{ 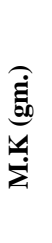 } & \multirow{2}{*}{$\sum_{\delta^{\circ}}^{4}$} & \multirow{2}{*}{ 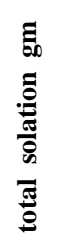 } & \multirow{2}{*}{ 突 } & \multirow{2}{*}{ 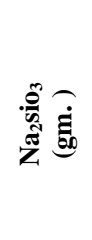 } & \multirow{2}{*}{ 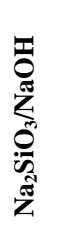 } & \multicolumn{4}{|c|}{$\mathrm{FC}_{3 \text { days }} \mathbf{k g} / \mathrm{cm}^{2}$} & \multicolumn{4}{|c|}{$\mathrm{FC}_{7 \text { days }} \mathbf{k g} / \mathrm{cm}^{2}$} & \multicolumn{4}{|c|}{$\mathrm{FC}_{28 \text { days }} \mathrm{kg} / \mathrm{cm}^{2}$} \\
\hline & & & & & & & & & & 离 & $\Xi$ & 鄢 & है & $\frac{\grave{ \pm}}{\pi}$ & : & 墕 & है & $\frac{\grave{\Xi}}{\tilde{E}}$ & 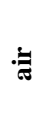 & $\frac{\Xi}{\tilde{E}}$ & ప \\
\hline OPC & o & o & 0 & 0 & 0 & तิ & ô & ô & ठี & $\stackrel{m}{\sim}$ & $\frac{m}{N}$ & 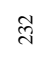 & $\stackrel{\infty}{\infty}$ & $\approx$ & in & 索 & $\stackrel{\infty}{\sim}$ & 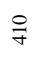 & $\approx$ & $\underset{\infty}{\infty}$ & 志 \\
\hline SN10 & 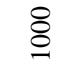 & ○ & 0 & 0 & 0 & $\stackrel{\text { ㄱ }}{\mathrm{N}}$ & $\begin{array}{l}0 \\
\dot{0} \\
\infty\end{array}$ & $\stackrel{\Xi}{\Xi}$ & $n$ & $\stackrel{\infty}{n}$ & $\underset{n}{\mathbb{n}}$ & $\stackrel{n}{\infty}$ & $\stackrel{\infty}{\infty}$ & 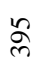 & $\frac{\mathfrak{I}}{F}$ & ঙิ & $\frac{m}{2}$ & $\stackrel{9}{4}$ & $\underset{\wp}{\infty}$ & 요 & 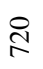 \\
\hline SR2 & \&ू & 8 & 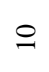 & $\circ$ & ○ & $\stackrel{8}{\circ}$ & $\begin{array}{l}\text { ते } \\
\text { ㄱ }\end{array}$ & $\stackrel{\sim}{\infty}$ & $n$ & $\stackrel{+}{+}$ & $\stackrel{?}{9}$ & $\underset{+}{\infty}$ & $\stackrel{\infty}{\pi}$ & 字 & ஓ & $\stackrel{\circ}{n}$ & 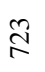 & $\stackrel{\infty}{0}$ & สิ & $\tilde{n}$ & $\widehat{N}$ \\
\hline SM1 & $\stackrel{\circ}{n}$ & ○ & $\circ$ & in & n & $\underset{\sim}{\stackrel{9}{d}}$ & $\begin{array}{l}0 \\
\infty \\
0\end{array}$ & $\stackrel{+}{\stackrel{5}{二}}$ & $\stackrel{n}{i}$ & \&े & $\stackrel{\infty}{\text { ले }}$ & $\frac{\vartheta}{\gamma}$ & $\stackrel{2}{i}$ & 年 & $\vec{\sigma}$ & $\begin{array}{l}\infty \\
\dot{q}+\infty \\
+\end{array}$ & $\hat{n}$ & $\bar{n}$ & in & $\stackrel{\infty}{n}$ & $\frac{7}{2}$ \\
\hline SMR & ஜ̊ & 8 & 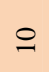 & in & in & $\underset{\mathrm{i}}{\mathrm{N}}$ & $\begin{array}{l}\text { ते } \\
\text { İ }\end{array}$ & $\stackrel{r}{\infty}$ & $\stackrel{n}{i}$ & \&े & $\stackrel{\mathscr{\infty}}{+}$ & $\stackrel{\circ}{\sigma}$ & $\frac{g}{i}$ & $\stackrel{q}{q}$ & $\frac{2}{n}$ & m & 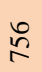 & ซิ & ? & $\ddot{0}$ & $\stackrel{\infty}{\sim}$ \\
\hline
\end{tabular}

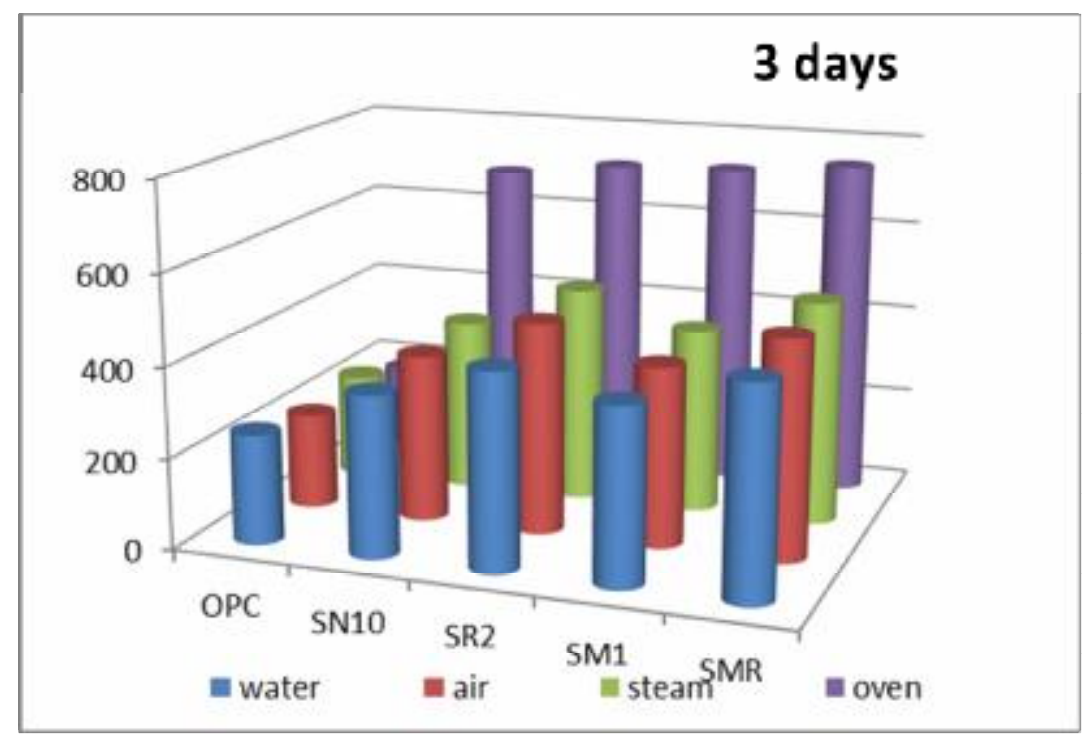

Figure (17) shown Optimizations of Na2SiO3: NaoH \& R.M Sand M.K ratio with different condition 


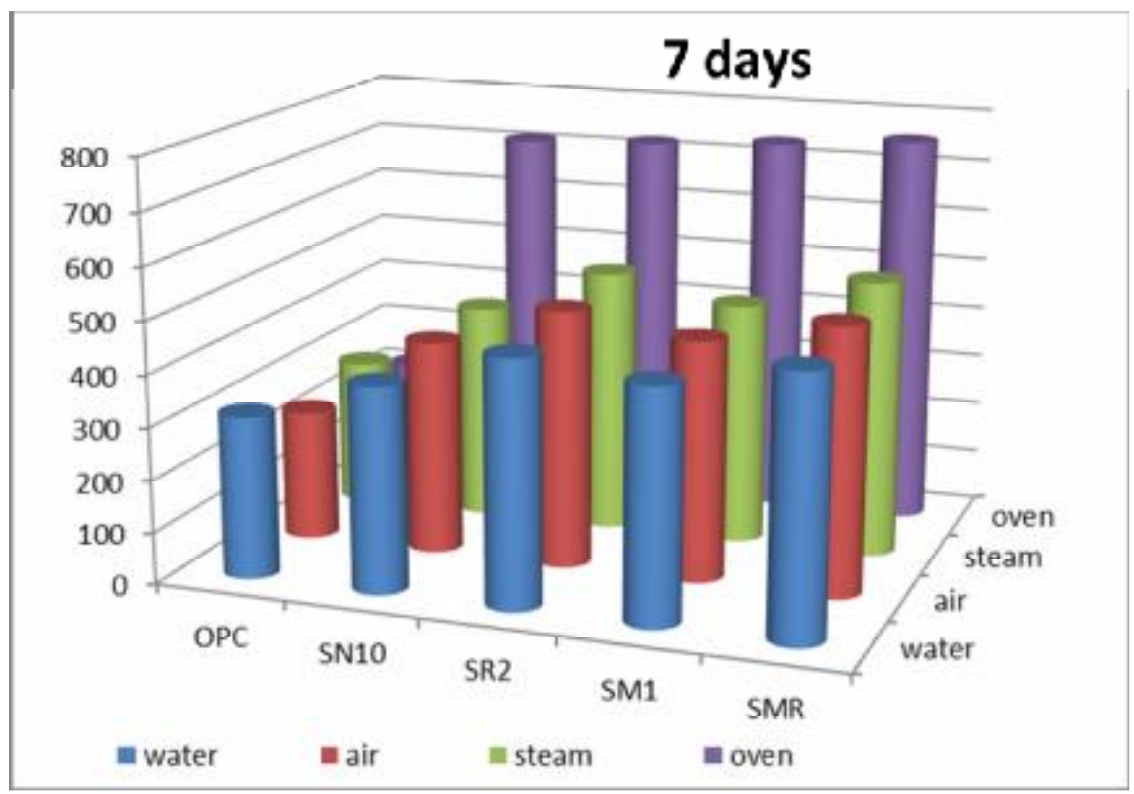

Figure (18) shown Optimizations of Na2SiO3: NaoH \& R.M and M.K ratio with different condittion

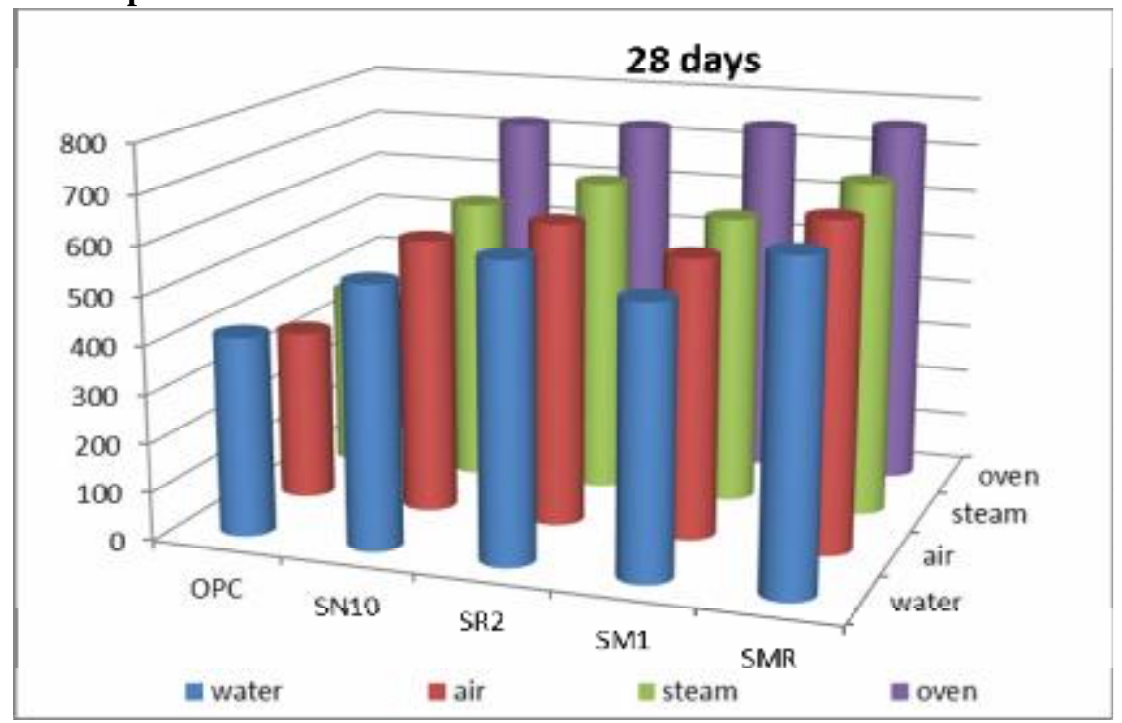

Figure (19) shown Optimizations of Na2SiO3: NaoH \& R.M and M.K ratio with different condition Conclusion.

The following statements were concluded from the results obtained:

- Geopolymer concrete can be used as an effective replacement for cement concrete thereby reduces environmental pollution as in case of cement concrete.

- The use of Portland cement has been completely eliminated; thereby reduce the emission of $\mathrm{CO}_{2}$ to the atmosphere which results in the reduction of Green House Gases

- using activators combined from sodium silicate and sodium hydroxide better than using actavitor sodium hydroxide only .

- Slag geopolymer can improve by replacement by Metakoline.

- Geopolymer structure gets more stable form in presence of MK.

- Slag geopolymer can improve by replacement by Red mud.

- Geopolymer structure gets more stable form in presence of RM.

- Using binder combined from Metakoline, Red mud and better than binder slags only.

- curing oven the best curing method in case geopolymer cement, but in case ordinary cement is curing water. 


\section{REFERENCES}

1- Parthiban. K and Vaithianathan. S, year 2015 [ Effect of Kaolin Content and Alkaline Concentration on the Strength Development of Geopolymer Concrete], International Journal of ChemTech Research, ISSN: 0974-4290 Vol.8, No.4, pp 1730-1734.

2- Sonal P. Thakkar, ${ }_{1}$, Darpan J. Bhorwani, Rajesh Ambaliya 3 , in year 2014 [ Geopolymer Concrete Using Different Source Material ], International Journal of Emerging Technology and Advanced Engineering, Volume 4, Special Issue 4, ISSN 2250-2459

3- Fenghong Fan, B.S , M, in year 2015, [mechanical and thermal properties of fly ashbased geopolymer cement ]

4- Ryno Barnard Prof WP Boshoff, Department of Civil Engineering the Faculty of Engineering aStellenbosch University, in year 2015

[Mechanical properties of fly ash/slag based geopolymer concrete with the addition of macro fibres .

5- Parthiban. K and Saravana Raja Mohan. K, in year 2014, Effect of Sodium

Hydroxide Concentration and Alkaline Ratio on the Compressive Strength of Slag Based Geopolymer Concrete, International Journal of ChemTech Research CODEN (USA): IJCRGG ISSN : 0974-429 Vol.6, No.4, pp 2446-2450, July-Aug 2014 .

6- Djwantoro Hardjito, Steenie E. Wallah, Dody M.J. Sumajouw, and B.V. Rangan, in year 2004, factors influencing the compressive strength of fly ash-based geopolymer concrete, Civil Engineering Dimension, Vol. 6, No. 2, 88-93, , ISSN 1410-9530

7- Manimaran, E and 2Mohankumar, G. Research Scholar, in year 2017 Mortar strength of Low calcium Fly ash based Geopolymer, IOSR Journal of Electrical and Electronics Engineering (IOSR-JEEE) e-ISSN: 2278-1676,p-ISSN: 2320-3331, Volume 12, Issue 1 Ver. III (Jan. - Feb. 2017), PP 01-05.

8- Ekom Eduok Institutt for matematikk og naturvitskap Universitet i , in year 2016, Thermal properties of geopolymer materials, Institutt for matematikk og naturvitskap Universitet i Stavanger, Norway.. 


\title{
DEVELOPMENT OF GEOPOLYMER (GREEN) CEMENT STRENGTH WITHOUT NATURAL AND CHEMICALS ADDITIVE.
}

\author{
${ }^{1}$ A. R. Abd EL-Moatey, ${ }^{2}$ I.El- Rashed, ${ }^{3}$ W.Al-Saed and W. H. Soufy ${ }^{4}$ \\ ${ }^{1}$ Civil Engineers - ministry of housing, utilities and new urban communities. \\ 2 projects mangment, Faculty of engineering, Ain shamis University. \\ ${ }^{3}$ Irrigation and Hydraulics. Faculty of Eng., Al-Azhar University \\ ${ }^{4}$ Housing and Building National Research Center (HBRC), Cairo, Egypt.
}

\begin{abstract}
Geopolymer cement (GPC) is made from aluminum and silicon, instead of calcium and silicon (OPC). Geopolymer are a type of inorganic polymer that can be formed at room temperature by using industrial waste (waste materials) such as ground granulated blast-furnace slag (GGBFS), Metakilon (MK) and Red mud (RD) or by products as source materials to form a solid binder that looks like and performs a similar function to OPC. Geopolymer concrete gets advantage specification in resistivity to highly aggressive media and the resistivity to change in mechanical and physical characterization at high temperature compared to the traditional concrete. this paper mainly study the preparation of Geopolymer cement to using in concrete instead of Portland cement and discuss the effect different factors on the compressive strength of Geopolymer paste without natural and chemicals additive (the effect ratio of (slag , Metakilon, Red mud, sodium hydroxide and sodium silicate) Four parameters were studied. The first parameter, the effect of changing ratio between sodium hydroxide and sodium silicate. $\mathrm{NaOH}$ : $\mathrm{Na} 2 \mathrm{SiO} 3$, secondly the effect of changing ratio between slag and Metakilon GGBFS :MK, thirdly the effect of changing ratio between slag and Red mud GGBFS :RM, fourthly the effect of changing degree curing temperature all samples curing different condition such as air, water, steam, oven. The results show that get high compressive strength at ratio between sodium hydroxide and sodium silicate $\left(\mathrm{NaOH}: \mathrm{Na}_{2} \mathrm{SiO}_{3}\right)$, slag and Metakilon (GGBFS :MK), slag and Red mud ( GGBFS :RM) is 1:2.5, 0.95:0.05, 0.90:0.10 respectively and the best mix have high compressive strength at various combinations between slag, Metakilon and Red mud by ratio GGBFS : MK : RM is 0.85:0.05:0.10. By inspecting the result it can be noticed that in case geopolymer concrete the best curing method gives high compressive strength in oven are compared air, steam, water and steam curing is better than air, water and air curing is better than water curing and the effect temperature curing type on compressive strength, Regardless of the compressive strength of samples increases with the increase in curing temperature.
\end{abstract}

\section{KEYWORDS: Kaolin Content and Alkaline Concentration, Strength Development,} Geopolymer cement, Red mud.

\section{INTRODUCTION}

Today one of the problems in building technology is the environmental pollution produced from cement. In the construction industry mainly the production of ordinary Portland cement (OPC) will cause the emission of pollutants which results in environmental pollution. There are three disadvantages of ordinary Portland cement the production. The emission of large amounts of carbon dioxide $\mathrm{CO}_{2}$ during the production of ordinary. Causing pollution of the 
atmosphere besides causing degradation of earth due to mining activities for limestone, Required Large amounts of energy.

Due to the excessive use of OPC, environmental concerns developed regarding the damage caused during the extraction of the raw materials and due to the large amount of $\mathrm{CO}_{2}$ emissions during the manufacturing process of OPC. It should be noted that the production of $\mathrm{OPC}$ is only an issue due to the large quantity that is produced each year. Compared to other materials, such as steel and aluminum, less energy is used to produce OPC. In seeking for solutions to reduce Global warming and the high amount of $\mathrm{CO}_{2}$ emissions, researchers introduced a new kind of binder known as alkali activated cement or better known as geopolymers cement.

The geopolymer technology shows considerable promise for application in the concrete industry as an alternative binder to the Portland cement. Proposed that an alkaline liquid could be used to react with the Silica (Si) and Aluminum (Al) in a source material of geological origin or in by product materials such as Ground Granulated Blast Furnace Slag (GGBS) powder, Metakilon to produce binders. Because the chemical reaction that takes place in this case is a polymerization process, the term geopolymer to represent these binders.

Geopolymer concrete there is often confusion between the meanings of the two terms 'geopolymer cement' and 'geopolymer concrete'. A cement is a binder whereas concrete is the composite material resulting from the addition of cement to stone aggregates. In other words, to produce concrete one purchase cements (generally Portland cement or Geopolymer cement) and adds it to the concrete batch. Geopolymer chemistry was from the start aimed at manufacturing binders and cements for various types of applications.

\section{Previous research}

In year 2015 Parthiban. K and Vaithianathan. S [1] Studied the strength characteristics of fly ash based geopolymer on different replacement levels of slag with met kaolin, sodium hydroxide concentration, maintaining the alkaline ratio constant at $\mathrm{NaOH}: \mathrm{Na}_{2} \mathrm{SiO}_{3}$ The tests includes cube compressive strength that approved that the compressive strength of geopolymer concrete increases with the increase in the Metakilon content and sodium hydroxide concentration. The mix with $12 \mathrm{M} \mathrm{NaOH}$ concentration and $20 \%$ Metakilon replacement shows optimum mix proportioning of the geopolymer concrete.

In year 2014 Sonal P. Thakkar, Darpan J. Bhorwani, Rajesh Ambaliya 3 [2] discusses various combinations of Ground Granulated Blast Furnace Slag (GGBFS) and Fly Ash, as source material, to produce geopolymer concrete at ambient temperature. Who that geopolymer concrete with GGBFS in Fly ash as increases it gains strength and shows good strength at 3, 7 and 28 days even at ambient curing with increase in GGBFS content. While only slag based geopolymer concrete has higher strength at oven curing while the rate of gain of strength is slower at ambient temperature as period increases.

In year 2014 Parthiban. K* and Saravana Raja Mohan. K [5] investigated has been made to study the variation in the Compressive Strength of slag based Geopolymer concrete of varying the concentration of Sodium hydroxide as $10,12,14 \mathrm{M}$ and the ratio of alkaline solution (SiO32- / OH-) as 1.0, 1.5, 2.0. The compressive strength of the mixes was determined in their 3, 7, 14 and 28 days curing for studying there variation at different age of curing. The test results show that the compressive strength of the Geopolymer mixes increases with the increase in the $\mathrm{NaOH}$ concentration and alkaline ratio.

In year 2015 Fenghong Fan [3] show that the Geopolymer cement cured at appropriate conditions can reach a compressive strength of more than $100 \mathrm{MPa}$ and it also has an excellent heat resistance with a remarkable strength after the $500^{\circ} \mathrm{C}$ heating. In addition, it is found that the studied Geopolymer cement possesses a much higher resistivity when immediately cooled down by water after the high temperature heating than the ordinary Portland cement concrete which has a high spallation tendency. These findings indicate that 
the Geopolymer cement may be an excellent construction material for the fire protection and fire-prone structures.

\section{Objective and scope}

Studying some factor effect on compressive strength such as the effect of Sodium silicate and sodium hydroxide $\left(\mathrm{Na}_{2} \mathrm{SiO}_{3}: \mathrm{NaOH}\right)$ with different curing type, the effect variation of degree curing Temperature for $24 \mathrm{hr}$, the Effect Meta-kaolin (MK)and red mud ratio. Then combination those to evaluate the high compressive strength of Geopolymer concrete mixture with Mk and RD replaced in percentage to G.G.B.S without usage of ordinary Portland cement

\section{Significance}

This paper aims to reduce the usage of ordinary Portland cement and to improve the usage of the other by product G.G.B.S (Slag). This product helps in reducing the carbon emissions caused by the conventional concrete. This also produces high strength concretes with the use of nominal mixes when compared to conventional concrete.

\section{Materials}

The used materials in the present study were ground granulated blast-furnace slag (GGBFS), meta-kaolin (MK), and Red mud (RD) and activator solution (the sodium hydroxide solution $\mathrm{NaOH}$, the sodium silicate solution $\mathrm{Na}_{2} \mathrm{SiO}_{3}$. Table (1) present the chemical composition of material that measured by $\mathrm{X}$ - ray flourresence.

\section{Ground granulated blast furnace slag (GGBFS)}

Ground granulated blast-furnace slag was obtained by Iron and Steel factory- Helwan, Egypt. The GGBFS is an industrial by-product resulting from rapid water cooling of molten steel. It is known to have advantageous properties for the concrete industry as it is relatively inexpensive to obtain highly resistant to chemical attack and maintains excellent thermal properties. Major components of the investigated slag are $\mathrm{SiO}_{2}, \mathrm{CaO}, \mathrm{MgO}$ and $\mathrm{Al}_{2} \mathrm{O}_{3}$ (Table 1). The Egyptian slag is characterized by its high content of $\mathrm{BaO}, \mathrm{MgO}$ and $\mathrm{MnO}$ than the common international standard one. GGBFS is off-white and grey in colour and substantially lighter than Portland cement. It was used as the basic aluminosilicate material to manufacture geopolymers.

\section{Meta-kaolin (MK):}

Kaolin material was extracted from the kaolinitic sandstone deposits existed in an open quarry located in Sinai west of Gebel Gunna by Middle East Mining Company Kaolin contains hydroxyl ions that are strongly bonded to the aluminosilicate framework and can only be altered by the temperature range $550-750{ }^{\circ} \mathrm{C}$ to be metakaolinite. Thus, rearranging the atomic structure to forma partly ordered system with a great reaction potential to alkaline solutions. The main chemical compositions of the studied meta- kaolin are $\mathrm{SiO}_{2}$ and $\mathrm{Al}_{2} \mathrm{O}_{3}$. Table (1) tabulated the chemical composition of calcined kaolin.

\section{Clay brick waste (Red mud (RM)).}

Clay brick waste (Red mud (RM)) can be defined as defective and crushed fired clay bricks. It was provided from clay brick factories, Helwan, Egypt. The main chemical compositions of the used RM are silica, alumina, in addition to a minor amount of iron oxides in a descending order of abundance (Table 1). 

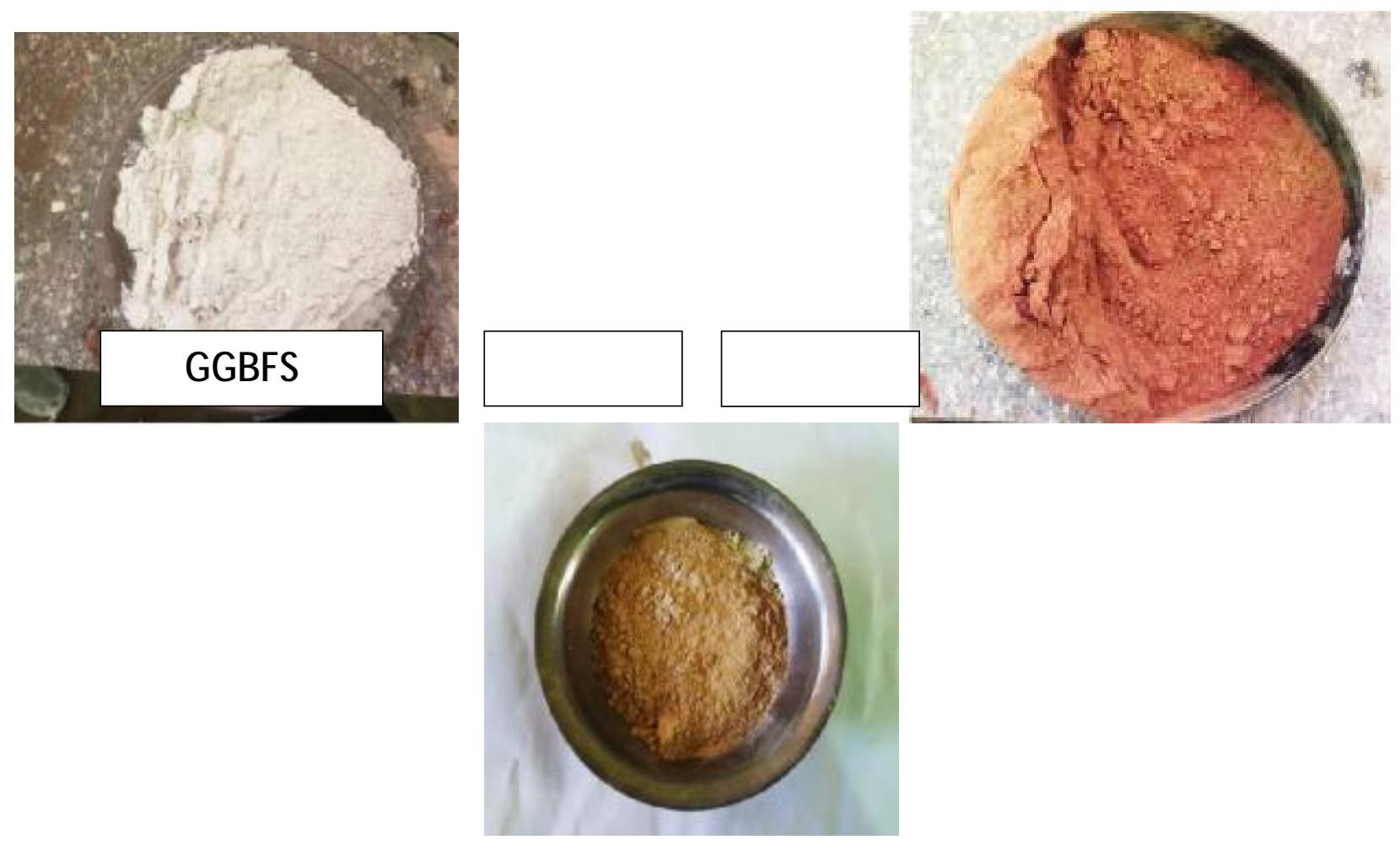

Figure (1) GGBFS, MK, RM

Table (1) X-ray (XRF) analysis of slag GGBFS, metakilon MK and Red mud RM.

\begin{tabular}{|c|c|c|c|c|c|c|c|c|c|c|c|c|c|c|}
\hline $\begin{array}{c}\text { Chemical } \\
\text { compounds }\end{array}$ & $\mathrm{CaO}$ & $\mathrm{SiO}_{2}$ & $\mathrm{Al}_{2} \mathrm{O}_{3}$ & $\mathrm{MgO}$ & $\mathrm{Na}_{2} \mathrm{O}$ & $\mathrm{SO}_{3}$ & $\mathrm{P}_{2} \mathrm{O}_{5}$ & $\mathrm{~K}_{2} \mathrm{O}$ & $\mathrm{TiO}_{2}$ & $\mathrm{MnO}_{2}$ & $\mathrm{Fe}_{2} \mathrm{O}_{3}$ & $\mathrm{SO}_{4}$ & $\mathrm{Cl}$ & $\mathrm{LOI}$ \\
\hline GGBS & 33.07 & $\mathbf{3 6 . 5 9}$ & $\mathbf{1 0 . 0 1}$ & $\mathbf{6 . 4 3}$ & $\mathbf{1 . 3 9}$ & $\mathbf{3 . 5 2}$ & $\mathbf{0 . 1 0}$ & $\mathbf{0 . 7 4}$ & $\mathbf{0 . 5 2}$ & $\mathbf{3 . 4 4}$ & $\mathbf{1 . 4 8}$ & $\mathbf{0 . 0 8}$ & $\mathbf{0 . 0 5}$ & $\mathbf{2 . 5 8}$ \\
\hline $\mathrm{RM}$ & $\mathbf{1 . 3 5}$ & $\mathbf{7 3 . 0 5}$ & $\mathbf{1 3 . 4 1}$ & $\mathbf{1 . 4 6}$ & $\mathbf{1 . 6 2}$ & $\mathbf{0 . 7 4}$ & $\mathbf{0 . 0 2}$ & $\mathbf{0 . 9 1}$ & $\mathbf{0 . 0 2}$ & $\mathbf{0 . 0 3}$ & $\mathbf{6 . 3 5}$ & $\mathbf{0 . 0 0}$ & $\mathbf{0 . 1 8}$ & $\mathbf{0 . 8 6}$ \\
\hline $\mathrm{MK}$ & $\mathbf{0 . 1 4}$ & $\mathbf{5 5 . 0 1}$ & $\mathbf{4 0 . 9 4}$ & $\mathbf{0 . 3 4}$ & $\mathbf{0 . 0 9}$ & $\mathbf{0 . 0 0}$ & $\mathbf{0 . 0 0}$ & $\mathbf{0 . 6 0}$ & $\mathbf{0 . 5 5}$ & $\mathbf{0 . 0 0}$ & $\mathbf{0 . 5 5}$ & $\mathbf{0 . 0 0}$ & $\mathbf{0 . 0 0}$ & $\mathbf{1 . 5 4}$ \\
\hline
\end{tabular}

\section{ACTIVATOR SOLUTION (NAOH, $\mathrm{NA}_{2} \mathrm{SIO}_{3}$ )}

Sodium silicate $\left(\mathrm{Na}_{2} \mathrm{SiO}_{3}\right)$ and Sodium hydroxide $(\mathrm{NaOH})$ based alkali activators were used for activating the geopolymerization process. $\mathrm{Na}_{2} \mathrm{SiO}_{3}$ is a white viscous liquid. Its chemical composition is $8.9 \% \mathrm{Na}_{2} \mathrm{O}, 28.7 \% \mathrm{SiO}_{2}$ and $62.5 \% \mathrm{H}_{2} \mathrm{O}$ (by weight) with specific gravity 1.41. $\mathrm{NaOH}$ is on form of white pellets with $99 \%$ purity. $\mathrm{NaOH}$ solution was prepared at desired molarity and kept in air for one day prior to mixing. With specific gravity 1.32 the concentration of the sodium hydroxide solution used from 12 molar (M) without additional water.

\section{Experimental Investigation}

\section{Preparation of Geopolymer paste}

$480 \mathrm{~g}$ (molarity x molecular weight) of sodium hydroxide flakes dissolved in one litre of water to prepare sodium hydroxide solution of $12 \mathrm{M}$. The mass of $\mathrm{NaOH}$ solids in a solution vary depending on the concentration of the solution

expressed in terms of molar, M. The mass of $\mathrm{NaOH}$ solids was measured as $372 \mathrm{~g}$ per $\mathrm{kg}$ of $\mathrm{NaOH}$ solution of $12 \mathrm{M}$ concentration. The sodium hydroxide solution is mixed with sodium silicate solution to get the desired alkaline solution one day before making the Geopolymer concrete. After solution is prepared the composition is weighed and mixed in concrete mixture as conventional concrete and transferred into moulds as early as possible as the setting times are low. 


\section{MIXING AND CASTING}

It was found that the fresh Geopolymer masonry mix was grey in colour and was cohesive. The amount of water in the mix played an important role on the behavior of fresh mix. Davidovits (2002) suggested that it is preferable to mix the sodium silicate solution and the sodium hydroxide solution together at least one day before adding the liquid to the solid constituents. The author suggested that the sodium silicate solution obtained from the market usually is in the form of a dimmer or a trimmer, instead of a monomer, and mixing it together with the sodium hydroxide solution assists the polymerization process.

Using the steel moulds Cubic's of $50 \times 50 \times 50 \mathrm{~mm}$ the one group is three cubic Following mixing, the materials were cast in prism moulds to produce samples of $50 \times 50 \times 50 \mathrm{~mm}$ for casting paste (binder, activator)

The effects of water content in the mix and the mixing time were identified as test parameters in the detailed study. From the preliminary work; it was decided to observe the following standard process of mixing in all further studies. Mix sodium hydroxide solution and sodium silicate solution together at least one day prior to adding the liquid to the dry materials. Mix all dry materials in the pan mixer for about three minutes. Add the liquid component of the mixture at the end of dry mixing, and continue the wet mixing for another four minutes. Compaction of fresh concrete in the cube moulds was achieved by compacting on a vibration table for ten seconds. After casting, the specimens were left undisturbed for 24 hours.

\section{CURING}

Curing is not required for these Geopolymer blocks. The heat gets liberated during the preparation of sodium hydroxide which should be kept undisturbed for curing in air. The moulds were covered by plastic film to avoid evaporation of water in case curing steam; the specimens were cured in water, oven at $80{ }^{\circ} \mathrm{C}$ for $24 \mathrm{hr}$

\section{TESTING}

The specimens were tested as per IS 516:1959 and strengths were calculated for 3, 7 and 28 days and the results were tabled.

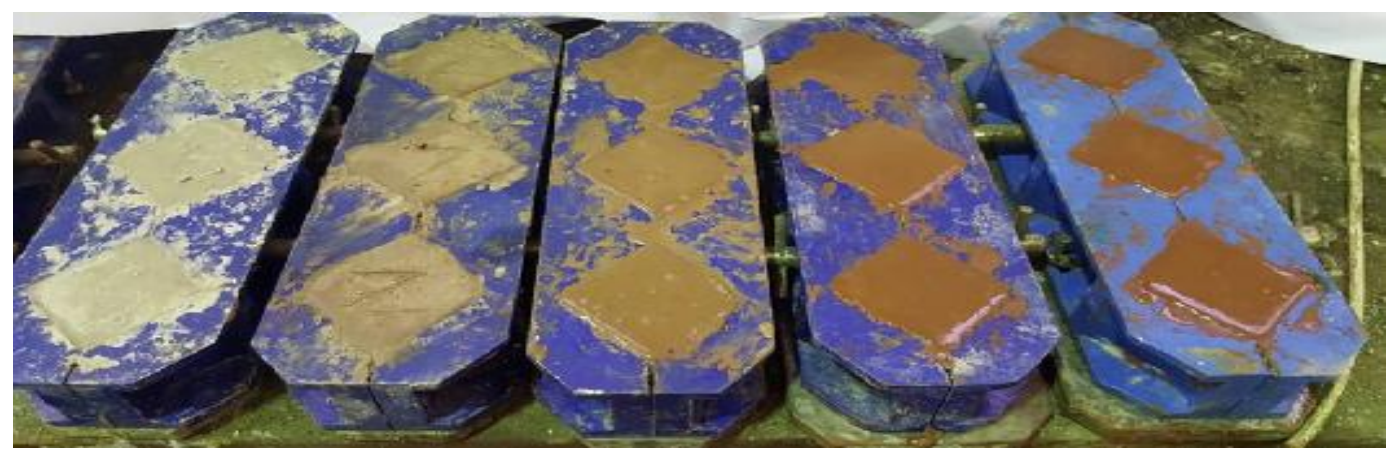

Figure 2 moulds $\mathbf{5 0} \times \mathbf{5 0} \times \mathbf{5 0} \mathrm{mm}$

\section{RESULTS AND DISCUSSION.}

\section{The effect of Sodium silicate and sodium hydroxide $\left(\mathrm{Na}_{2} \mathrm{SiO}_{3}: \mathrm{NaoH}\right)$ with different curing type}

Table (2) shows the compressive strength of geoplymer cement based slag "SN" samples with various Sodium silicate $\left(\mathrm{Na}_{2} \mathrm{SiO}_{3}\right)$ and Sodium hydroxide $(\mathrm{NaOH})$. And it can be noticed the effect curing type on compressive strength " water, air, wet air and oven " curing for 24 hours $\left(80^{\circ} \mathrm{C}\right)$ conditions. For all geopolymer mixes, the proportion of activator solution to geopolymer binder (24\%) by weight for paste. Also, reference samples of OPC were prepared with water cement ratio (W/C) of 0.25 in order to give the same workability of geopolymer pastes and due to the water required for cement paste of standard consistency test. 
DEVELOPMENT OF GEOPOLYMER (GREEN) CEMENT STRENGTH WITHOUT NATURAL AND CHEMICALS ADDITIVE.

Table (2) shown The Inflecune ratio of Sodium silicate and sodium hydroxide on compressive strength

\begin{tabular}{|c|c|c|c|c|c|c|c|c|c|c|c|c|c|c|c|c|}
\hline \multicolumn{17}{|c|}{ effect of $\mathrm{Na}_{2} \mathrm{Sio}_{3}$ ratio on compressive strength } \\
\hline \multirow[t]{2}{*}{ sample } & \multirow[t]{2}{*}{$\%$ slag } & \multirow[t]{2}{*}{$\% \mathrm{NaOH}$} & \multirow[t]{2}{*}{$\% \mathrm{Na}_{2} \mathrm{SiO}_{3}$} & \multirow[t]{2}{*}{$\mathrm{Na}_{2} \mathrm{SiO}_{3}: \mathrm{NaOH}$} & \multicolumn{4}{|c|}{$\mathrm{FC}_{3 \text { days }} \mathrm{Kg} / \mathrm{cm}^{2}$} & \multicolumn{4}{|c|}{$\mathrm{FC}_{7 \text { days }} \mathrm{Kg} / \mathrm{cm}^{2}$} & \multicolumn{4}{|c|}{$\mathrm{FC}_{28 \text { days }} \mathrm{Kg} / \mathrm{cm}^{2}$} \\
\hline & & & & & water & air & steam & oven & water & air & steam & oven & water & air & steam & oven \\
\hline OPC & $\mathbf{0}$ & $\mathbf{0}$ & $\mathbf{0}$ & OPC & 243 & 213 & 232 & 183 & 312 & 250 & 284 & 218 & 410 & 352 & 380 & 284 \\
\hline SNo & 100 & $\mathbf{0}$ & 1 & 01:00 & 20 & 26 & 43 & 185 & 32 & 45 & 67 & 213 & 88 & 112 & 119 & 219 \\
\hline SN1 & 100 & 4 & 1 & 0.25 & 204 & 213 & 224 & 485 & 268 & 305 & 324 & 490 & 398 & 456 & 478 & 560 \\
\hline SN2 & 100 & 3.5 & 1 & 0.28 & 216 & 223 & 236 & 496 & 294 & 312 & 336 & 512 & 408 & 472 & 494 & 575 \\
\hline SN3 & 100 & 3 & 1 & 0.33 & 219 & 234 & 245 & 503 & 298 & 314 & 349 & 526 & 413 & 488 & 500 & 587 \\
\hline SN4 & 100 & 2.5 & 1 & 0.4 & 221 & 237 & 251 & 530 & 306 & 319 & 359 & 544 & 418 & 494 & 512 & 610 \\
\hline SN5 & 100 & 2 & 1 & 0.5 & 225 & 241 & 259 & 544 & 316 & 328 & 362 & $\mathbf{5 5 0}$ & 434 & 506 & 518 & 612 \\
\hline SN6 & 100 & 1.5 & 1 & 0.66 & 234 & 245 & 270 & 567 & 328 & 337 & 375 & 576 & 464 & 529 & 540 & 637 \\
\hline SN7 & 100 & 1 & 1 & 1 & 260 & 274 & 287 & 590 & 341 & 348 & 380 & 612 & 471 & 538 & 545 & 645 \\
\hline SN8 & 100 & 1 & 1.5 & 1.5 & 300 & 324 & 334 & 632 & 353 & 364 & 391 & 640 & 483 & 544 & 564 & 680 \\
\hline SN9 & 100 & 1 & 2 & 2 & 342 & 357 & 363 & 670 & 373 & 386 & 408 & 690 & 488 & 550 & 573 & 688 \\
\hline SN10 & 100 & 1 & 2.5 & 2.5 & 358 & 372 & 385 & 688 & 395 & 412 & 420 & 713 & 540 & 568 & 590 & 720 \\
\hline SN12 & 100 & 1 & 3 & 3 & 352 & 361 & 389 & 677 & 380 & 394 & 411 & 695 & 490 & 559 & 612 & 691 \\
\hline SN13 & 100 & 1 & 3.5 & 3.5 & 296 & 308 & 321 & 540 & 318 & 331 & 342 & 548 & 402 & 412 & 415 & 490 \\
\hline SN14 & 100 & 1 & 4 & 4 & 210 & 218 & 228 & 442 & 245 & 228 & 245 & 481 & 370 & 376 & 384 & 371 \\
\hline SN15 & 100 & 1 & o & 0 & 188 & 203 & 210 & 312 & 196 & 217 & 219 & 316 & 212 & 226 & 239 & 320 \\
\hline
\end{tabular}

By inspecting the values in table (2), it can be concluded that sample SN10 gives the highest compressive strength over the other samples for all curing conditions. Regardless of the curing method, the compressive strength of samples increases with the increase in Sodium Silicate: Sodium hydroxide ratio $(\mathrm{Na} 2 \mathrm{SiO} 3: \mathrm{NaOH})$. This increase peaks at ratio of 2.5:1 then it reverses its pace. Also, it can be noticed that oven curing leads to the highest compressive strength for all samples, then steam curing, and then air curing and the least values are related to water curing (see figures 1,2, 3 and 4). Moreover, figure 5 illustrates that oven curing results in high early strength. 
DEVELOPMENT OF GEOPOLYMER (GREEN) CEMENT STRENGTH WITHOUT NATURAL AND CHEMICALS ADDITIVE.

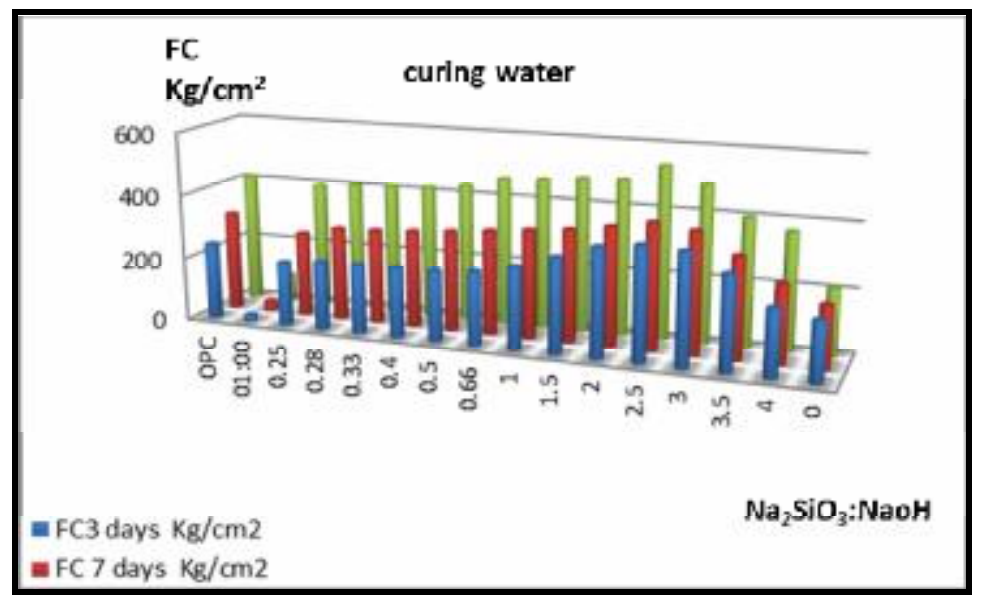

Figure (3) shown effect of $\mathrm{Na} 2$ sio3 ratio on compressive strength in case water curing

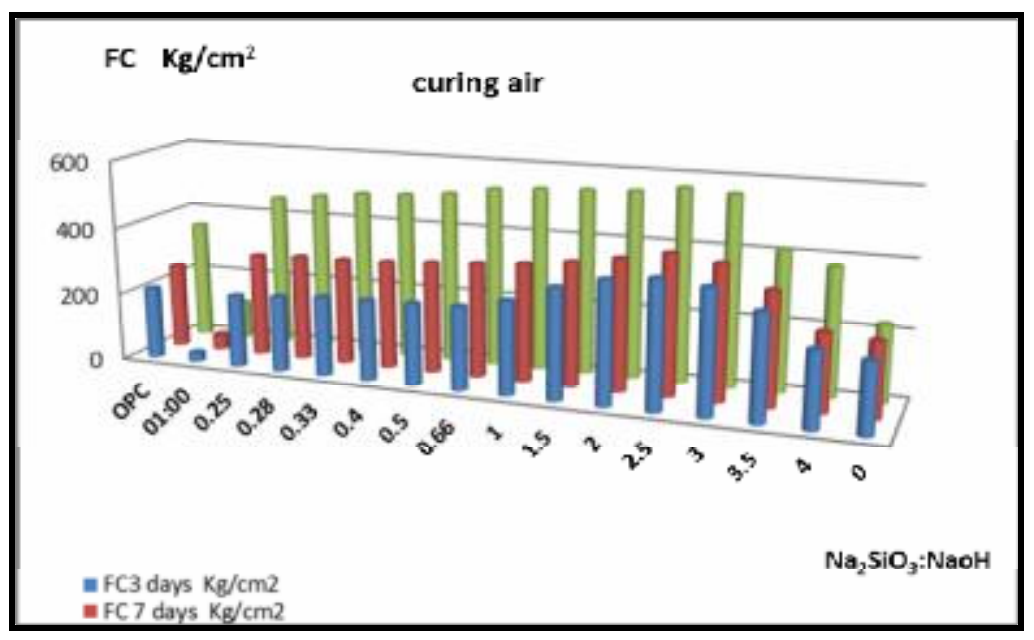

Figure (4) shown effect of $\mathrm{Na} 2 \operatorname{sio3}$ ratio on compressive strength in case air curing

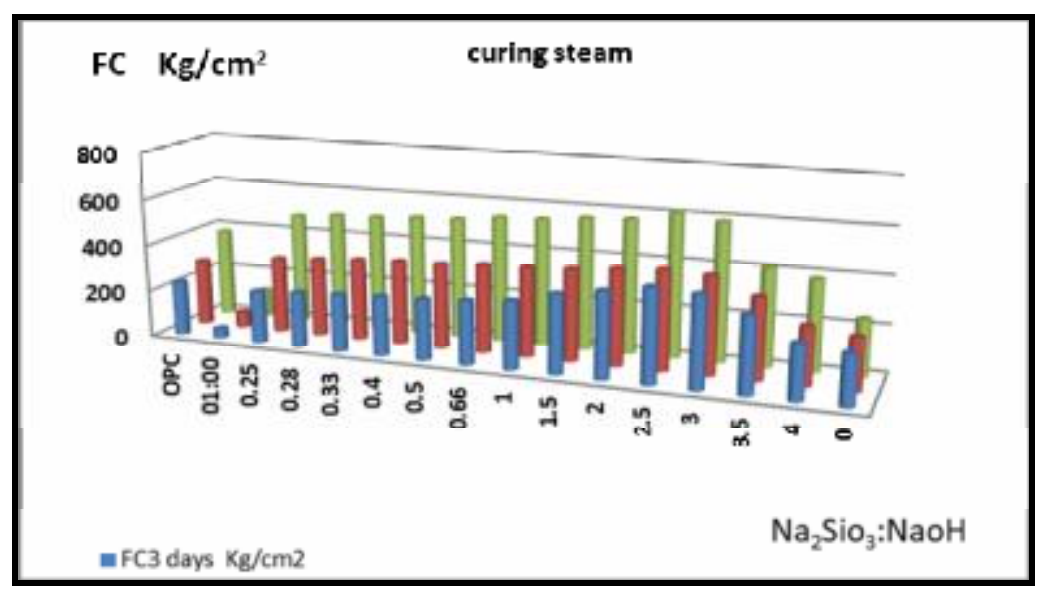

Figure (5) shown effect of $\mathrm{Na2sio3}$ ratio on compressive strength in case steam curing 


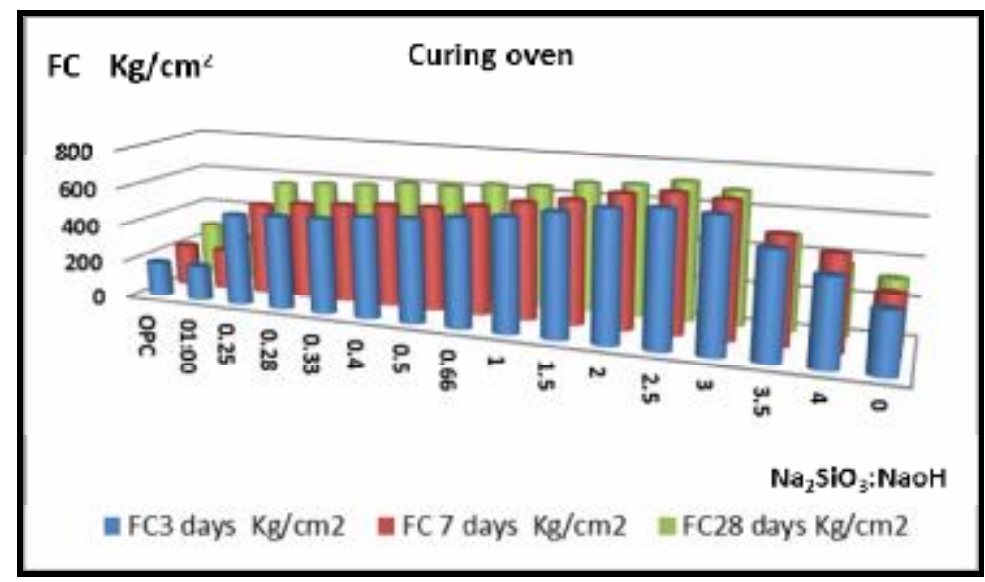

Figure (6) shown effect of $\mathrm{Na} 2 \operatorname{sio3}$ ratio on compressive strength in case oven curing

From fig $(3,4,5,6,7)$ can be concluded that in case Geopolymer concrete the best curing method gives high compressive strength in oven are compared air, steam, water, steam curing is better than air, water and air curing is better than water .

On the other side oven curing shows significant increase in compressive strength which reaches to 1.8 of water curing at 28 days and the most of strength geopolymer paste get in 3 day in case oven curing .

From fig $(3,4,5,6,7)$ can be concluded that in case Portland concrete the best curing method gives high compressive strength in water are compared air, steam, oven, steam curing is better than air, oven and air curing is better than oven.

\section{The variation of degree curing Temperature for $24 \mathrm{hr}$ on compressive strength}

Table (3) Shown The variation of degree curing temperature on compressive strength

\begin{tabular}{|c|c|c|c|c|c|c|c|c|c|}
\hline \multicolumn{10}{|c|}{ effect of degree curing temperature } \\
\hline sample & $\begin{array}{l}\text { slag } \\
(\mathrm{gm})\end{array}$ & $\begin{array}{c}\mathrm{NaoH} \\
(\mathrm{gm})\end{array}$ & $\begin{array}{c}\mathrm{Na}_{2} \mathrm{siO}_{3} \\
(\mathrm{gm})\end{array}$ & $\mathrm{Na}_{2} \mathrm{SiO}_{3}: \mathrm{NaOH}$ & T,Curing & $\mathrm{fc}_{3}$ & $\mathrm{fc}_{7}$ & $\mathrm{fc}_{28}$ & Curing \\
\hline $\mathrm{ST}_{1}$ & 1000 & 68.6 & 171.4 & 2.5 & 50 & 488 & 490 & 512 & \multirow{6}{*}{ oven } \\
\hline $\mathrm{ST}_{2}$ & 1000 & 68.6 & 171.4 & 2.5 & 60 & 554 & 562 & 571 & \\
\hline $\mathrm{ST}_{3}$ & 1000 & 68.6 & 171.4 & 2.5 & 70 & 569 & 576 & 594 & \\
\hline $\mathrm{ST}_{4}$ & 1000 & 68.6 & 171.4 & 2.5 & 80 & 590 & 595 & 622 & \\
\hline $\mathrm{ST}_{5}$ & 1000 & 68.6 & 171.4 & 2.5 & 90 & 616 & 618 & 640 & \\
\hline $\mathrm{ST}_{6}$ & 1000 & 68.6 & 171.4 & 2.5 & 100 & 643 & 647 & 680 & \\
\hline
\end{tabular}

Table (3) shows the compressive strength of geoplymer cement based slag "ST" samples with Sodium silicate $(\mathrm{Na} 2 \mathrm{SiO} 3)$ and Sodium hydroxide $(\mathrm{NaOH})$ is $2.5: 1$. And it can be noticed the effect temperature curing type on compressive strength, Regardless of the compressive strength of samples increases with the increase in curing temperature, Moreover, figure 8 illustrates that oven curing results in high early strength. By inspecting the values in fig 8 , it can be concluded that sample ST6 gives the highest compressive strength over the other samples for all curing temperature. 


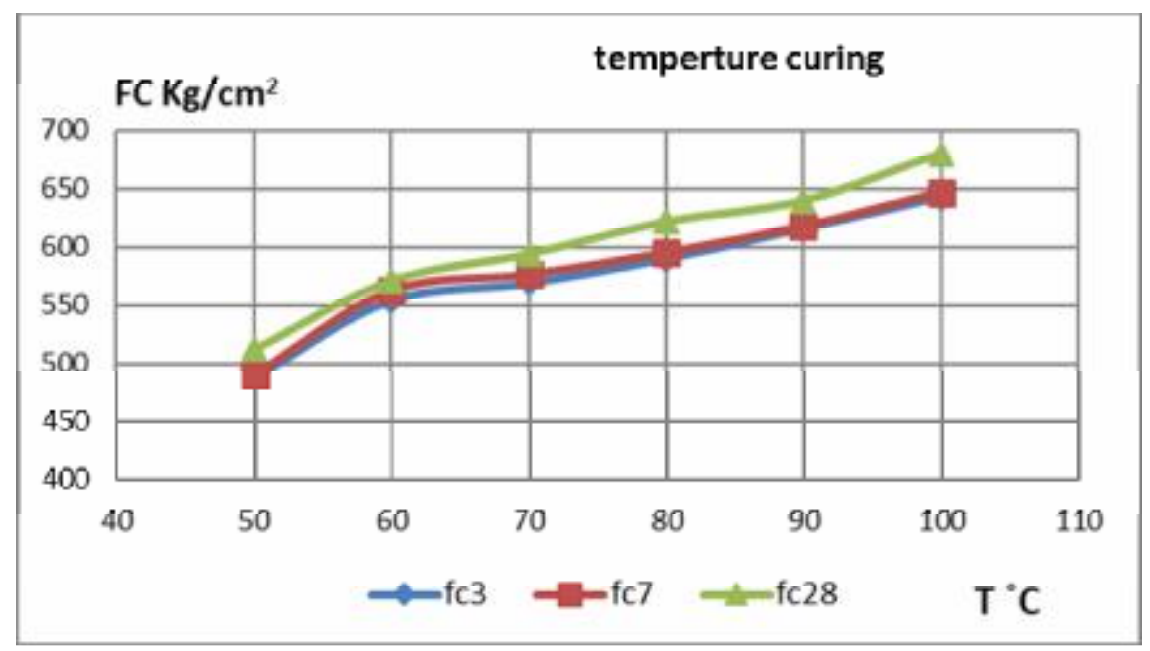

Figure (8) shown effect of curing temperature on compressive strength in case oven curing

\section{The effect Meta-kaolin (MK) on compressive strength}

In this part study effect metakoalin ratio on compressive strength slag - based Geopolymer, The replacement ratio ranged from 0 to $20 \%$ (by weight) for meta kaolin and the samples were denoted as "SM" samples. With Sodium silicate $\left(\mathrm{Na}_{2} \mathrm{SiO}_{3}\right)$ and Sodium hydroxide $(\mathrm{NaOH})$ is $2.5: 1$

Table (4) The Effect of M.K ratio on compressive strength

\begin{tabular}{|c|c|c|c|c|c|c|c|c|c|c|c|c|c|c|c|c|c|c|}
\hline \multicolumn{19}{|c|}{ effect of M.K ratio on compressive strength } \\
\hline \multirow{2}{*}{ sample } & \multirow{2}{*}{$\begin{array}{l}\text { slag } \\
(\mathrm{gm})\end{array}$} & \multirow{2}{*}{$\begin{array}{l}\text { M.K } \\
(\mathrm{gm})\end{array}$} & \multirow[t]{2}{*}{$\%$ M.K } & \multirow{2}{*}{$\begin{array}{l}\mathrm{NaoH} \\
(\mathrm{gm})\end{array}$} & \multirow{2}{*}{$\begin{array}{c}\mathrm{Na}_{2} \mathrm{Si}_{3} \\
(\mathrm{gm})\end{array}$} & \multirow{2}{*}{$\mathrm{Na}_{2} \mathrm{SiO}_{3} / \mathrm{NaOH}$} & \multicolumn{4}{|c|}{$\mathrm{FC}_{3 \text { days }} \mathrm{kg} / \mathrm{cm}^{2}$} & \multicolumn{4}{|c|}{$\mathrm{FC}_{7 \text { days }} \mathrm{kg} / \mathrm{cm}^{2}$} & \multicolumn{4}{|c|}{$\mathrm{FC}_{28 \text { days }} \mathrm{Kg} / \mathrm{cm}^{2}$} \\
\hline & & & & & & & water & air & steam & oven & water & air & steam & oven & water & air & steam & oven \\
\hline OPC & 1000 & $\mathrm{OPC}$ & OPC & OPC & OPC & OPC & 243 & 213 & 232 & 183 & 312 & 250 & 284 & 218 & 410 & 352 & 380 & 284 \\
\hline SM0 & 1000 & 0 & 0 & 68.6 & 171.4 & 2.5 & 358 & 372 & 385 & 688 & 395 & 412 & 420 & 713 & 540 & 568 & 590 & 720 \\
\hline SM1 & 950 & 50 & 5 & 68.6 & 171.4 & 2.5 & 390 & 398 & 412 & 725 & 445 & 461 & 468 & 737 & 551 & 574 & 598 & 742 \\
\hline SM2 & 900 & 100 & 10 & 68.6 & 171.4 & 2.5 & 362 & 370 & 385 & 690 & 411 & 450 & 453 & 702 & 549 & 571 & 587 & 720 \\
\hline SM3 & 850 & 150 & 15 & 68.6 & 171.4 & 2.5 & 347 & 361 & 373 & 678 & 407 & 420 & 426 & 685 & 534 & 542 & 550 & 690 \\
\hline SM4 & 800 & 200 & 20 & 68.6 & 171.4 & 2.5 & 334 & 344 & 350 & 661 & 398 & 408 & 417 & 670 & 529 & 537 & 541 & 677 \\
\hline
\end{tabular}

Table (4) shows that the highest compressive strength was obtained in sample $\mathrm{SM}_{1}$ (replacement ratio $=5 \%$ ). Also, the compressive strength ratio between 7 and 28 days ranged from about 0.75 to 0.90 . This ratio tends to increase with the increase in MK replacement ratio. In air (ambient) curing, table 4 shown increases in compressive strength of Geopolymer cement based on slag with Meta Kaolin as a replacement material with time and this increase gets highly strength at sample $\mathrm{SM}_{1}$. These behaviors are matched with above determinations in air. But, in air the results get more strength values due to the vaporization of external water in geopolymer cement.

From fig $(9,10,11$, and 12) shown that geopolymer paste the best curing method gives high compressive strength in oven are compared air, steam and water.

Steam curing is better than air, water and air curing is better than water. We notice too that MK replacement ratio gives the best results incase offer to temperature. 
DEVELOPMENT OF GEOPOLYMER (GREEN) CEMENT STRENGTH WITHOUT NATURAL AND CHEMICALS ADDITIVE.

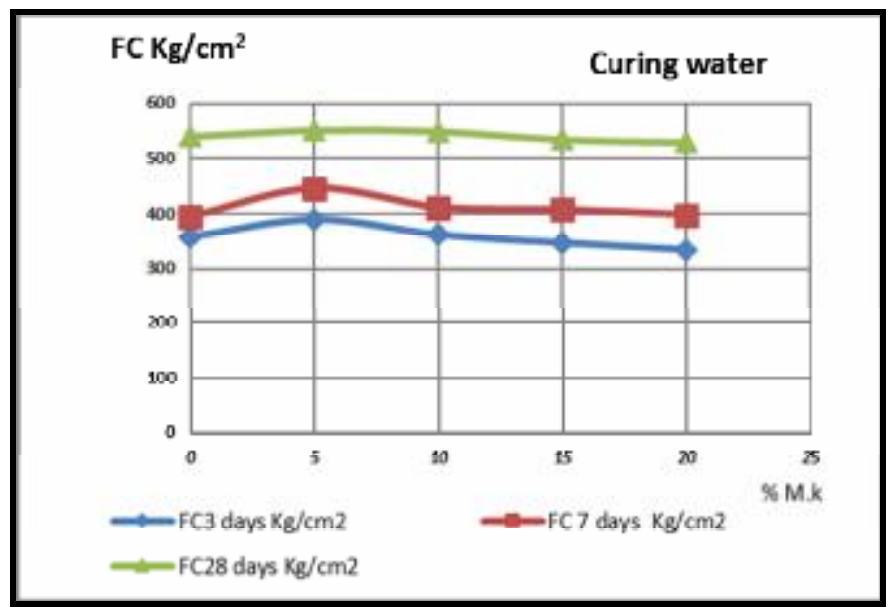

Figure (9) effect of M.K ratio on compressive strength in case water curing

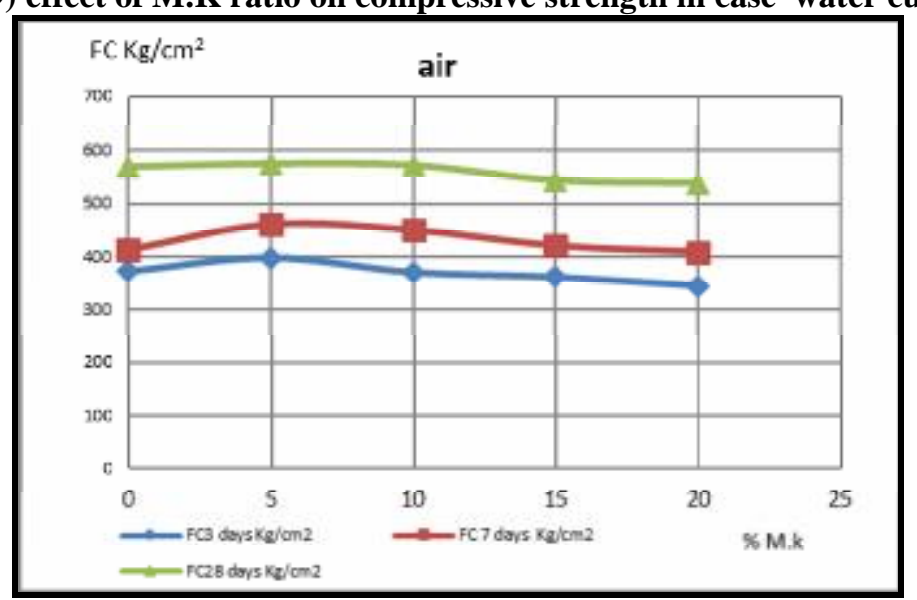

Figure (10) effect of M.K ratio on compressive strength in case air curing

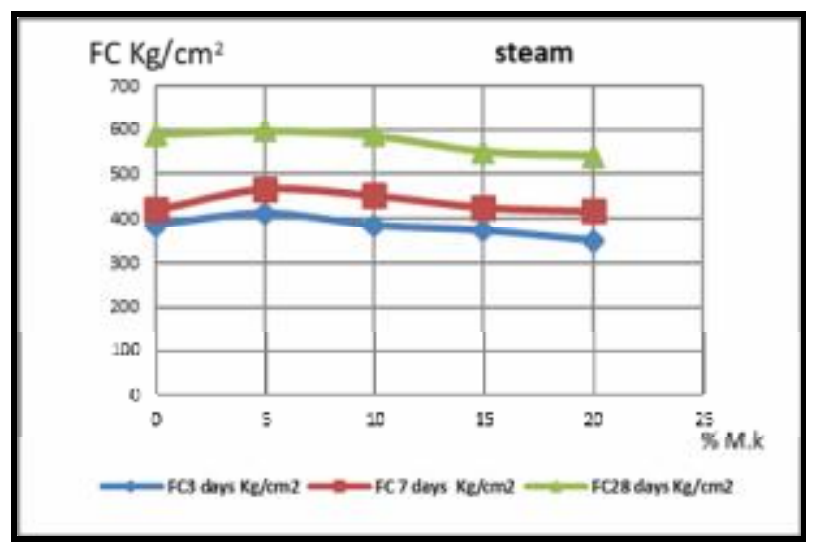

Figure (11) effect of M.K ratio on compressive strength in case steam curing 


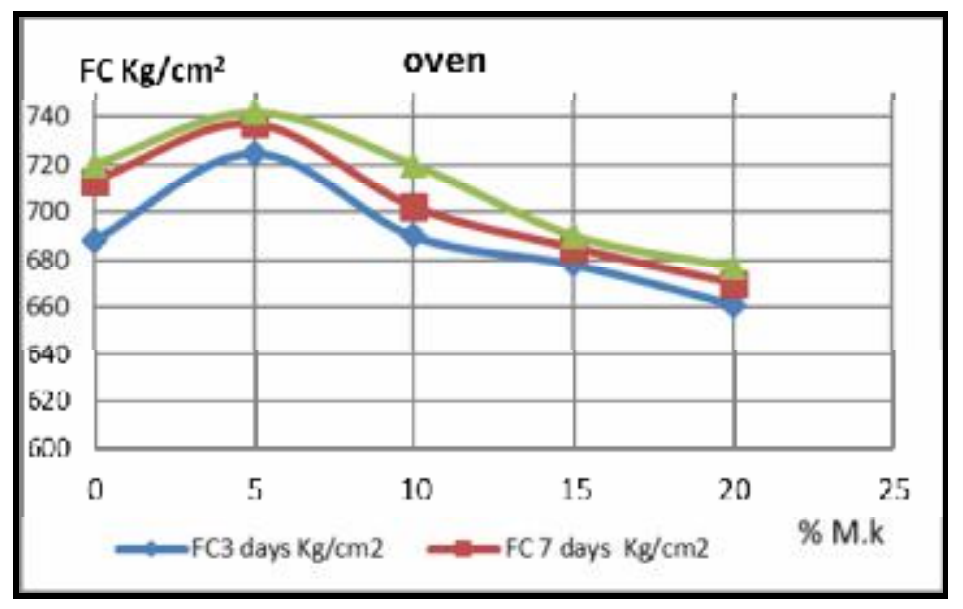

Figure (12) effect of M.K ratio on compressive strength in case oven curing

\section{The effect Red mud (R.M) on compressive strength}

In this part study effect red mud ratio on compressive strength slag - based Geopolymer, The replacement ratio ranged from 0 to $20 \%$ (by weight) for for red brick and the samples were denoted as "SR" samples. With Sodium silicate $\left(\mathrm{Na}_{2} \mathrm{SiO}_{3}\right)$ and Sodium hydroxide $(\mathrm{NaOH})$ is $2.5: 1$

Table (5) shown The Effect of RM ratio on compressive strength

\begin{tabular}{|c|c|c|c|c|c|c|c|c|c|c|c|c|c|c|c|c|c|c|c|}
\hline \multicolumn{20}{|c|}{ Effect of R.D ratio on compressive strength } \\
\hline \multirow{2}{*}{$\begin{array}{l}\text { sam } \\
\text { ple }\end{array}$} & \multirow{2}{*}{$\begin{array}{l}\text { slag } \\
(\mathrm{gm})\end{array}$} & \multirow{2}{*}{$\begin{array}{c}\mathbf{R M} \\
(\mathbf{g m})\end{array}$} & \multirow{2}{*}{$\% \mathrm{RM}$} & \multirow{2}{*}{$\begin{array}{c}\text { total } \\
\text { solati } \\
\text { on gm }\end{array}$} & \multirow{2}{*}{$\begin{array}{c}\mathrm{NaoH} \\
(\mathrm{gm})\end{array}$} & \multirow{2}{*}{$\begin{array}{c}\mathrm{Na}_{2} \mathrm{Sio}_{3} \\
(\mathrm{gm})\end{array}$} & \multirow{2}{*}{$\begin{array}{l}\mathrm{Na}_{2} \mathrm{SiO}_{3} / \\
\mathrm{NaOH}\end{array}$} & \multicolumn{4}{|c|}{$\mathrm{FC}_{3 \text { days }} \mathrm{Kg} / \mathrm{cm}^{2}$} & \multicolumn{4}{|c|}{$\mathrm{FC}_{7 \text { days }} \mathrm{Kg} / \mathrm{cm}^{2}$} & \multicolumn{4}{|c|}{$\mathrm{FC}_{28 \text { days }} \mathrm{Kg} / \mathrm{cm}^{2}$} \\
\hline & & & & & & & & water & air & steam & oven & water & air & Steam & oven & water & air & $\begin{array}{c}\text { stea } \\
\text { m }\end{array}$ & oven \\
\hline OPC & 1000 & OPC & OPC & 220 & OPC & OPC & OPC & 243 & 213 & 232 & 183 & 312 & 250 & 284 & 218 & 410 & 352 & 380 & 284 \\
\hline SR0 & 1000 & $\mathbf{0}$ & $\mathbf{0}$ & 240 & 68.6 & 171.4 & 2.5 & 358 & 372 & 385 & 695 & 395 & 412 & 420 & 704 & 540 & 568 & 590 & $\mathbf{7 2 0}$ \\
\hline SR1 & 950 & 50 & 5 & 240 & 68.6 & 171.4 & 2.5 & 374 & 395 & 398 & 701 & 414 & 429 & 442 & 710 & 553 & 589 & 604 & 722 \\
\hline SR2 & 900 & 100 & 10 & 260 & 74.29 & 185.7 & 2.5 & 434 & 470 & 482 & 718 & 471 & 496 & 510 & 723 & 608 & 622 & 653 & 727 \\
\hline SR3 & 850 & 150 & 15 & 280 & 80 & 200 & 2.5 & 420 & 433 & 456 & 706 & 457 & 470 & 478 & 714 & 564 & 599 & 612 & 725 \\
\hline SR4 & 800 & 200 & 20 & 300 & 85.71 & 214.3 & 2.5 & 389 & 400 & 434 & 703 & 427 & 449 & 461 & 712 & 559 & 590 & 608 & 723 \\
\hline
\end{tabular}

Table ( 5) depicts that the highest compressive strength was obtained in sample SR2 (replacement ratio $=10 \%$ ). Also, compressive strength gains at 7 days reached about $90 \%$ of its compressive strength at age 28 days. For the other samples, this ratio varied between 55 to $110 \%$ which means that number of samples suffered strength loss at 28 days. Moreover, sample SR4 which corresponds to the full replacement of GGBFS by RB shows the less compressive strength in comparison to other SR mixes. In air (ambient) curing, table 5 shown increases in compressive strength of Geopolymers cement based on slag with Red bricks as a replacement material with time and this increase gets highly strength at sample R2. 
DEVELOPMENT OF GEOPOLYMER (GREEN) CEMENT STRENGTH WITHOUT NATURAL AND CHEMICALS ADDITIVE.

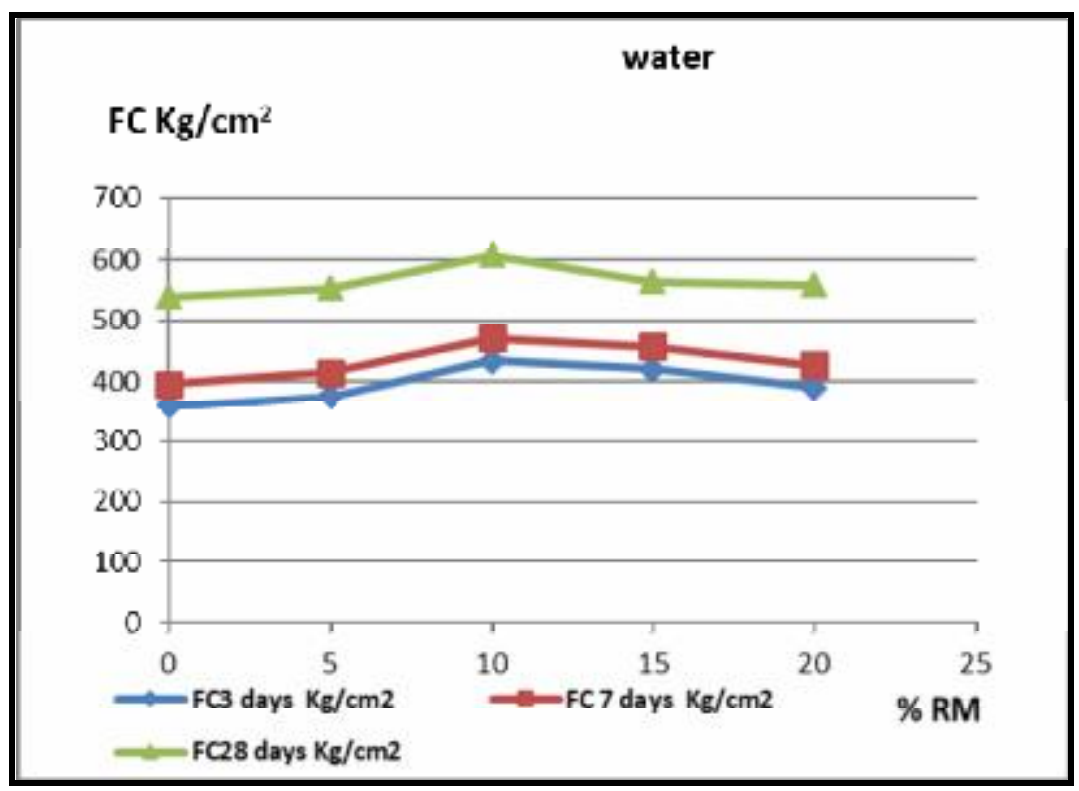

Figure (13) effect of $R D$ ratio on compressive strength in case water curing

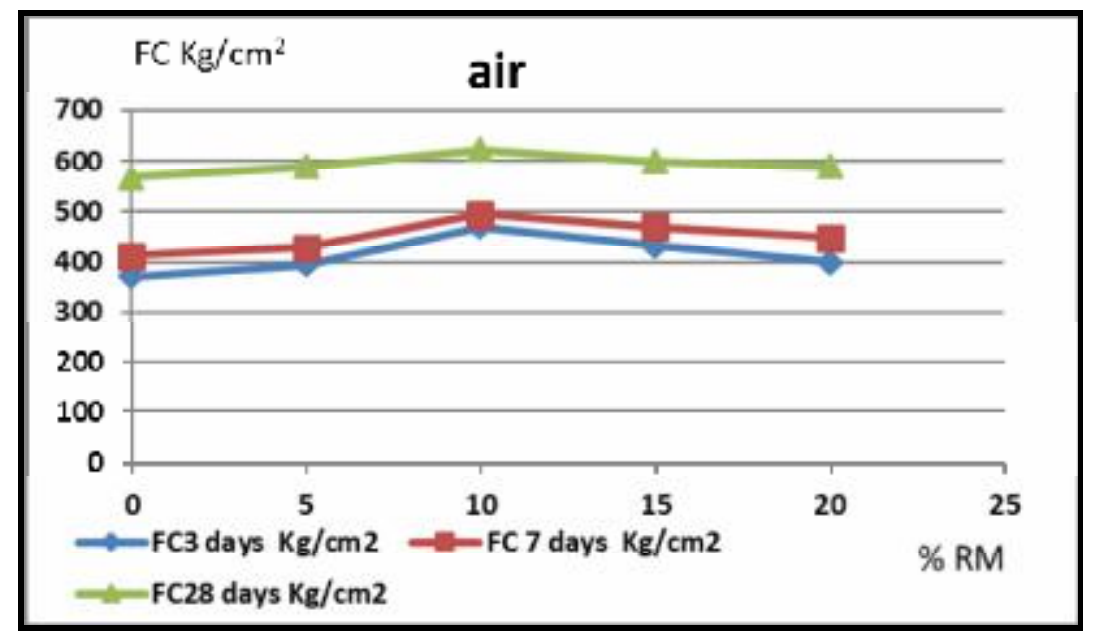

Figure (14) effect of $R D$ ratio on compressive strength in case air curing

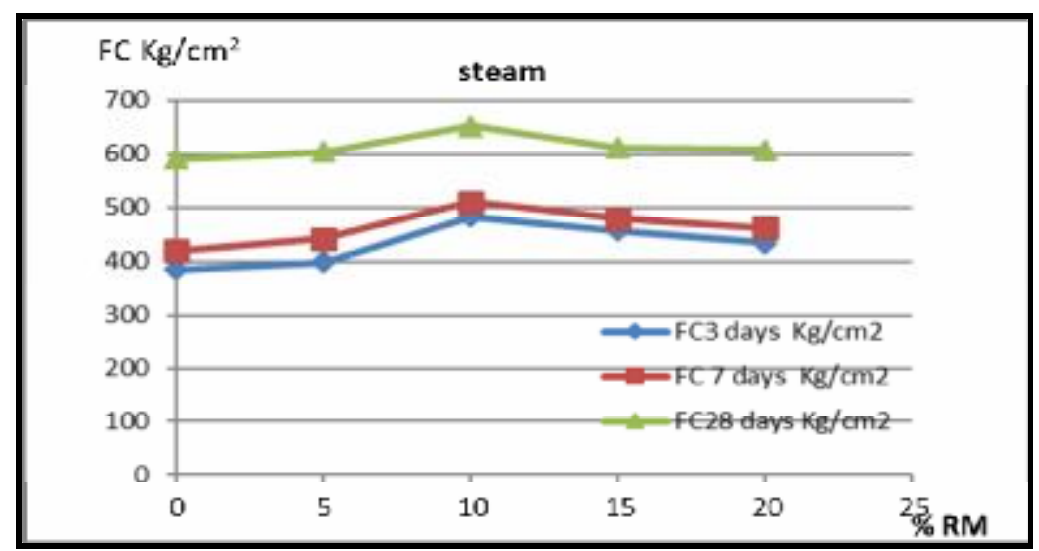

Figure (15) effect of RM ratio on compressive strength in case steam curing 


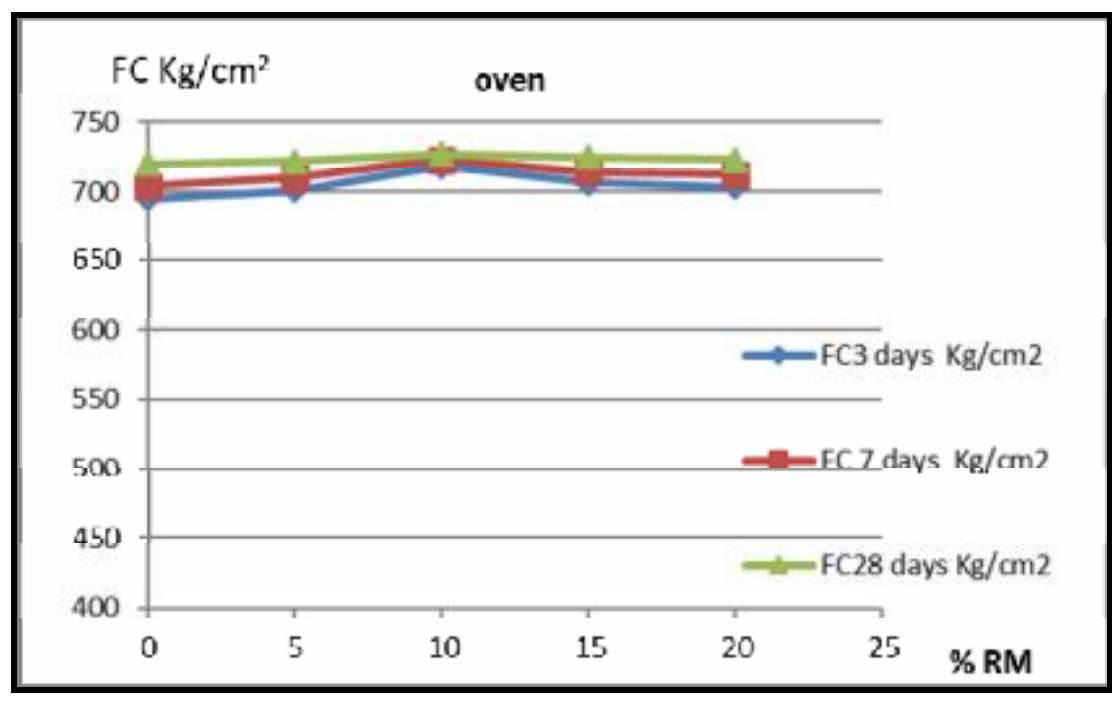

Figure (16) effect of M.K ratio on compressive strength in case oven curing

From fig $(13,14,15$ and 16) shown that geopolymer paste the best curing method gives high compressive strength in oven are compared air, steam and water.

steam curing is better than air, water and air curing is better than water. We notice too that RM replacement ratio gives the best results incase offer to temperature.

\section{COMBINATION OF NA2 $\mathrm{SIO}_{3}$ : NAOH, R.M AND M.K RATIO ON COMPRESSIVE STRENGTH.}

It is obvious that the partial replacements of GGBS by RM, MK, or a combination of some of them lead to higher compressive strengths. Also, all geopolymer samples showed higher strength than OPC with the same water ratio. The combination of factors to get high compressive strength ("SN", "ST", "SM", "SR") and the sample was denoted as "SP" samples. Table 6 gives a summary of chosen samples to be exposed to mechanical to OPC and SMR samples. As concluded from the previous tables samples $\mathrm{SN}_{10}, \mathrm{SR}_{2}$ and $\mathrm{SM}_{1}$ had shown highest compressive strength.

Figure $(16,17,18)$ shows the best ratio of activator solution, Sodium silicate $\left(\mathrm{Na}_{2} \mathrm{SiO}_{3}\right)$ and Sodium hydroxide $(\mathrm{NaOH})$ ratio is $\mathbf{S N}_{\mathbf{1 0}}$, the best that the partial replacements of GGBS by $\mathrm{MK}$ is $\mathbf{S M}_{\mathbf{1}}$, the best that the partial replacements of GGBS by RM is $\mathbf{S M}_{\mathbf{1}}$ and combination of $\mathbf{S M}_{\mathbf{1}}, \mathbf{S M}_{\mathbf{1}}$ and $\mathbf{S N}_{\mathbf{1 0}}$ to get $\mathbf{S M R}$ ( combined GGBFS +RM + MK )have higher compressive strength than $\mathbf{S M}_{\mathbf{1}}, \mathbf{S M}_{\mathbf{1}}, \mathbf{S N}_{\mathbf{1 0}}$ after 3,7 and 28 days. 
DEVELOPMENT OF GEOPOLYMER (GREEN) CEMENT STRENGTH WITHOUT NATURAL AND CHEMICALS ADDITIVE.

Table (6) shown Optimizations of Na2SiO3: NaoH, R.D and M.K ratio

\begin{tabular}{|c|c|c|c|c|c|c|c|c|c|c|c|c|c|c|c|c|c|c|c|c|c|}
\hline \multirow[b]{3}{*}{ sample } & \multicolumn{21}{|c|}{ Optimizations of $\mathrm{Na}_{2} \mathrm{SiO}_{3}: \mathrm{NaoH} \&$ R.D and $\mathrm{M} . \mathrm{K}$ ratio on compressive strength } \\
\hline & \multirow{2}{*}{ 焉 } & \multirow{2}{*}{$\sum_{\underline{\alpha}} \widehat{\dot{\vec{g}}}$} & \multirow{2}{*}{$\begin{array}{l}\sum_{\substack{0 \\
0}}^{0} \\
\delta^{\circ}\end{array}$} & \multirow{2}{*}{ 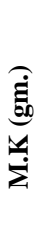 } & \multirow{2}{*}{$\sum_{\delta^{\circ}}^{4}$} & \multirow{2}{*}{ 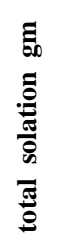 } & \multirow{2}{*}{ 突 } & \multirow{2}{*}{ 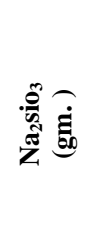 } & \multirow{2}{*}{ 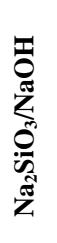 } & \multicolumn{4}{|c|}{$\mathrm{FC}_{3 \text { days }} \mathbf{k g} / \mathrm{cm}^{2}$} & \multicolumn{4}{|c|}{$\mathrm{FC}_{7 \text { days }} \mathbf{k g} / \mathrm{cm}^{2}$} & \multicolumn{4}{|c|}{$\mathrm{FC}_{28 \text { days }} \mathrm{kg} / \mathrm{cm}^{2}$} \\
\hline & & & & & & & & & & 离 & $\Xi$ & 鄢 & है & $\frac{\grave{ \pm}}{\pi}$ & : & 墕 & है & $\frac{\grave{\Xi}}{\tilde{E}}$ & 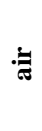 & $\frac{\Xi}{\tilde{E}}$ & ప \\
\hline OPC & o & o & 0 & 0 & 0 & तิ & ô & ô & ठี & $\stackrel{m}{\sim}$ & $\frac{m}{N}$ & 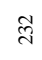 & $\stackrel{\infty}{\infty}$ & $\approx$ & in & 索 & $\stackrel{\infty}{\sim}$ & 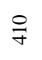 & $\approx$ & $\underset{\infty}{\infty}$ & 志 \\
\hline SN10 & 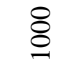 & ○ & 0 & 0 & 0 & $\stackrel{\text { ㄱ }}{\mathrm{N}}$ & $\begin{array}{l}0 \\
\dot{0} \\
\infty\end{array}$ & $\stackrel{\Xi}{\Xi}$ & $n$ & $\stackrel{\infty}{n}$ & $\underset{n}{\mathbb{n}}$ & $\stackrel{n}{\infty}$ & $\stackrel{\infty}{\infty}$ & 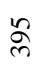 & $\frac{\mathfrak{I}}{F}$ & ঙิ & $\frac{m}{2}$ & $\stackrel{9}{4}$ & $\underset{\wp}{\infty}$ & 요 & 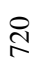 \\
\hline SR2 & \&ू & 8 & 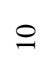 & $\circ$ & ○ & $\stackrel{8}{\circ}$ & $\begin{array}{l}\text { ते } \\
\text { ㄱ }\end{array}$ & $\stackrel{\sim}{\infty}$ & $n$ & $\stackrel{+}{+}$ & $\stackrel{?}{9}$ & $\underset{+}{\infty}$ & $\stackrel{\infty}{\pi}$ & 字 & ஓ & $\stackrel{\circ}{n}$ & 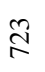 & $\stackrel{\infty}{0}$ & สิ & $\tilde{n}$ & $\widehat{N}$ \\
\hline SM1 & $\stackrel{\circ}{n}$ & ○ & $\circ$ & in & n & $\underset{\sim}{\stackrel{9}{d}}$ & $\begin{array}{l}0 \\
\infty \\
0\end{array}$ & $\stackrel{+}{\stackrel{5}{二}}$ & $\stackrel{n}{i}$ & \&े & $\stackrel{\infty}{\text { ले }}$ & $\frac{\vartheta}{\gamma}$ & $\stackrel{2}{i}$ & 年 & $\vec{\sigma}$ & $\begin{array}{l}\infty \\
\dot{q}+\infty \\
+\end{array}$ & $\hat{n}$ & $\bar{n}$ & in & $\stackrel{\infty}{n}$ & $\frac{7}{2}$ \\
\hline SMR & ஜ̊ & 8 & 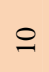 & in & in & $\underset{\mathrm{i}}{\mathrm{N}}$ & $\begin{array}{l}\text { ते } \\
\text { İ }\end{array}$ & $\stackrel{r}{\infty}$ & $\stackrel{n}{i}$ & \&े & $\stackrel{\mathscr{\infty}}{+}$ & $\stackrel{\circ}{\sigma}$ & $\frac{g}{i}$ & $\stackrel{q}{q}$ & $\frac{2}{n}$ & m & 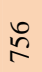 & ซิ & ? & $\ddot{0}$ & $\stackrel{\infty}{\sim}$ \\
\hline
\end{tabular}

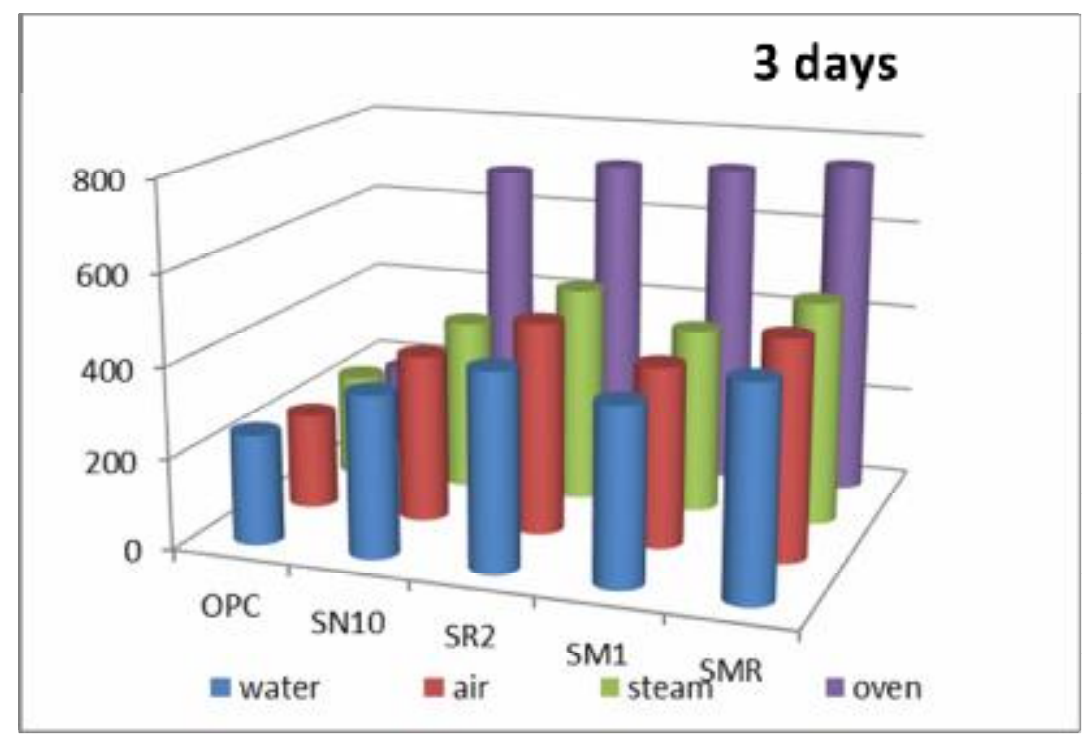

Figure (17) shown Optimizations of Na2SiO3: NaoH \& R.M Sand M.K ratio with different condition 


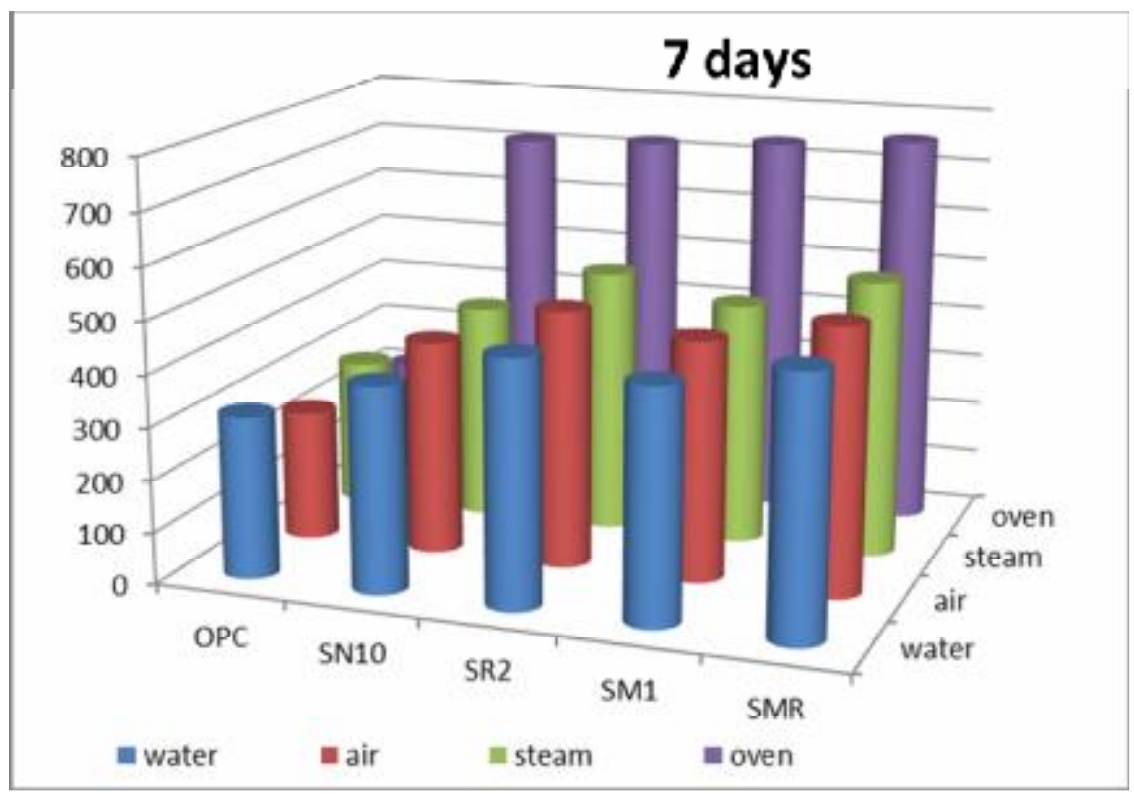

Figure (18) shown Optimizations of Na2SiO3: NaoH \& R.M and M.K ratio with different condittion

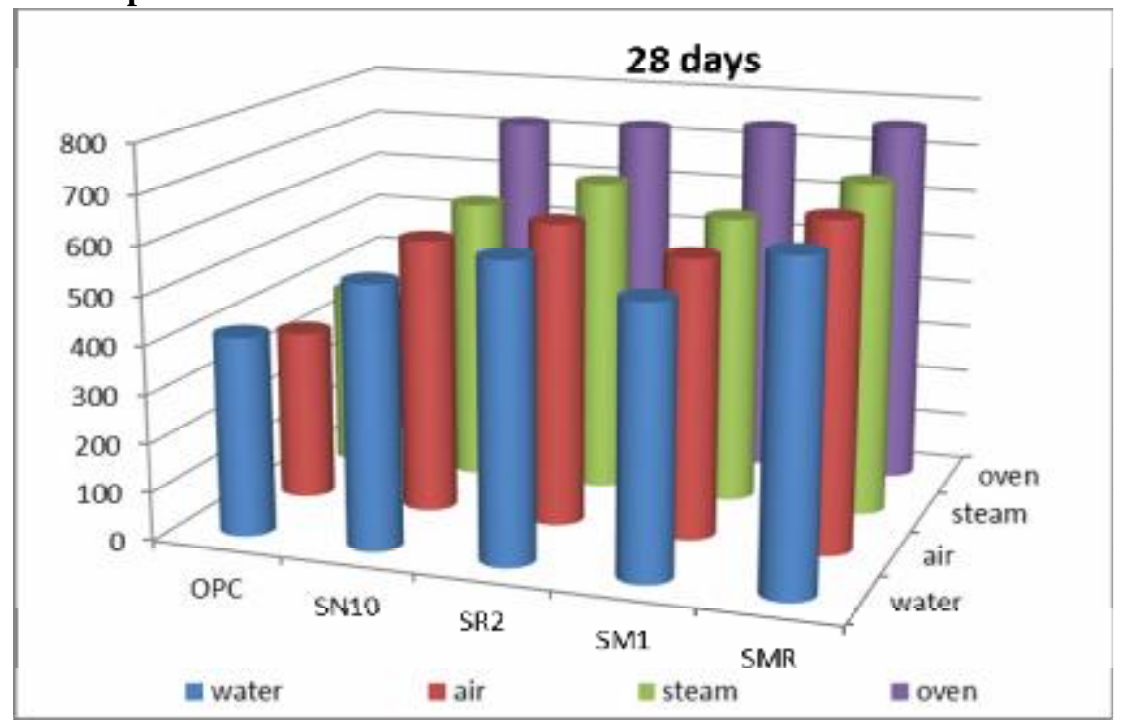

Figure (19) shown Optimizations of Na2SiO3: NaoH \& R.M and M.K ratio with different condition Conclusion.

The following statements were concluded from the results obtained:

- Geopolymer concrete can be used as an effective replacement for cement concrete thereby reduces environmental pollution as in case of cement concrete.

- The use of Portland cement has been completely eliminated; thereby reduce the emission of $\mathrm{CO}_{2}$ to the atmosphere which results in the reduction of Green House Gases

- using activators combined from sodium silicate and sodium hydroxide better than using actavitor sodium hydroxide only .

- Slag geopolymer can improve by replacement by Metakoline.

- Geopolymer structure gets more stable form in presence of MK.

- Slag geopolymer can improve by replacement by Red mud.

- Geopolymer structure gets more stable form in presence of RM.

- Using binder combined from Metakoline, Red mud and better than binder slags only.

- curing oven the best curing method in case geopolymer cement, but in case ordinary cement is curing water. 


\section{REFERENCES}

1- Parthiban. K and Vaithianathan. S, year 2015 [ Effect of Kaolin Content and Alkaline Concentration on the Strength Development of Geopolymer Concrete], International Journal of ChemTech Research, ISSN: 0974-4290 Vol.8, No.4, pp 1730-1734.

2- Sonal P. Thakkar, ${ }_{1}$, Darpan J. Bhorwani, Rajesh Ambaliya 3 , in year 2014 [ Geopolymer Concrete Using Different Source Material ], International Journal of Emerging Technology and Advanced Engineering, Volume 4, Special Issue 4, ISSN 2250-2459

3- Fenghong Fan, B.S , M, in year 2015, [mechanical and thermal properties of fly ashbased geopolymer cement ]

4- Ryno Barnard Prof WP Boshoff, Department of Civil Engineering the Faculty of Engineering aStellenbosch University, in year 2015

[Mechanical properties of fly ash/slag based geopolymer concrete with the addition of macro fibres .

5- Parthiban. K and Saravana Raja Mohan. K, in year 2014, Effect of Sodium

Hydroxide Concentration and Alkaline Ratio on the Compressive Strength of Slag Based Geopolymer Concrete, International Journal of ChemTech Research CODEN (USA): IJCRGG ISSN : 0974-429 Vol.6, No.4, pp 2446-2450, July-Aug 2014 .

6- Djwantoro Hardjito, Steenie E. Wallah, Dody M.J. Sumajouw, and B.V. Rangan, in year 2004, factors influencing the compressive strength of fly ash-based geopolymer concrete, Civil Engineering Dimension, Vol. 6, No. 2, 88-93, , ISSN 1410-9530

7- Manimaran, E and 2Mohankumar, G. Research Scholar, in year 2017 Mortar strength of Low calcium Fly ash based Geopolymer, IOSR Journal of Electrical and Electronics Engineering (IOSR-JEEE) e-ISSN: 2278-1676,p-ISSN: 2320-3331, Volume 12, Issue 1 Ver. III (Jan. - Feb. 2017), PP 01-05.

8- Ekom Eduok Institutt for matematikk og naturvitskap Universitet i , in year 2016, Thermal properties of geopolymer materials, Institutt for matematikk og naturvitskap Universitet i Stavanger, Norway.. 